\title{
POLYGENETIC TOPOGRAPHY OF THE CASCADE RANGE, WASHINGTON STATE, USA
}

\author{
SARA GRAN MITCHELL ${ }^{\dagger} * * * *$ and DAVID R. MONTGOMERY*
}

\begin{abstract}
We evaluate models for the Cenozoic topographic evolution of the Cascade Range of Washington State by analyzing the topography, geology, and exhumation patterns across the range. The models for topographic evolution include: 1) post-Miocene surface uplift of the range from initially low-relief topography, 2) post-Miocene surface uplift of the range superimposed on pre-existing high-relief topography, and 3) post-Miocene surface uplift of high-relief Cascades in northern Washington and low-relief Cascades in southern Washington. The third model-a polygenetic topographic history-is most consistent with our analysis of topographic data and the previously contradictory geologic, paleontologic, and isotopic lines of evidence regarding the Cascades physiographic history. Between Snoqualmie Pass and the Columbia River, the east-derived, $\sim 15$ My-old Columbia River Basalt (CRB) reaches nearly as far west as the modern drainage divide and is warped upward to the crest of the range. These observations require subdued relief on the east flank of the southern Cascades during the late Miocene. In the northern Cascades, the CRB does not extend into the range and CRB deformation only reflects 30 to 60 percent of the total relief. Thus, the northern Cascades were likely already a topographic barrier to the west-flowing flood basalts. Moreover, a polygenetic topographic history appears most consistent with the geologic data and the paleontologic and isotopic evidence for rainshadow formation during the middle Miocene. Despite differences in topographic history and rock type, the maximum and mean altitudes of the Cascade Range decrease smoothly from northern to southern Washington. We suggest that post-uplift erosion, particularly glacial erosion, has reduced the topographic distinctions between the northern and southern Cascades, resulting in a single mountain range with a polygenetic topographic history.
\end{abstract}

\section{INTRODUCTION}

The surface uplift and modern topography of a mountain range are usually interpreted as the result of a single, though perhaps complex, orographic event; a classic example is the rise of the Himalaya from the continental collision of the Indian Plate with Asia since 50 My ago (Searle and Treloar, 1993). However, the long-term topographic history of mountainous regions is often obscured by deformation and/or erosion and by the problem that only indirect indications of paleo-elevation are typically available. Hence, separating exhumation from surface uplift is often problematic (England and Molnar, 1990), and it is not often clear how many orogenic events contributed to the development of the modern topography of a particular range. In this study, we investigate the topographic evolution of the Cascade Range of Washington State, a mountain range with several unusual qualities. First, the topography of this range is the result of both tectonic uplift of bedrock and the processes associated with an active magmatic arc. Second, the Cascades in Washington represent the boundary between the Coast Mountains, which extend north to Alaska, and the Cascade arc, which extends south to California. Despite these complexities, the Cascade Range in Washington State is now a continuous mountain range. Here, we synthesize previous studies and present new analyses to show that the modern landscape is the result of a mountain building history that is complex in both time and space. Specifically, we

*Department of Earth and Space Sciences, Box 351310, University of Washington, Seattle, Washington 98195, USA

**Present address: Department of Biology, College of the Holy Cross, P.O. Box B, 1 College Street, Worcester, Massachusetts 01610, USA

${ }^{\dagger}$ Corresponding author: smitchel@holycross.edu 
update, extend, and combine analyses of geologic and topographic data to evaluate the different models proposed for the Cenozoic topographic evolution of the Cascade Range in Washington.

Within Washington State, the Cascade Range extends approximately $150 \mathrm{~km}$ west to east and spans the state's $400 \mathrm{~km}$ north-to-south distance (fig. 1A). The range is located $\sim 200 \mathrm{~km}$ inland from the Cascadia subduction zone, the active tectonic boundary that forms the border between the North American and Juan de Fuca plates (fig. 1B). Terrane accretion, collisional deformation, continental volcanic arc activity, erosion, and sedimentation within the past $200 \mathrm{My}$ have all contributed to the geologic and topographic complexity of western Washington (for example, Christiansen and others, 1992). The spectacular Quaternary volcanoes in the Cascades, including Mount Rainier, Mount St. Helens, Mount Adams, Glacier Peak, and Mount Baker, are magmatic arc volcanoes related to the ongoing subduction of the Juan de Fuca plate; however, these young volcanoes form relatively minor features on the broad antiform that creates most of the relief of the range. Our goals are to decipher the general altitude and relief patterns of the Cascades in Washington prior to the recent rock and surface uplift of the range, and to evaluate the paleotopography and the recent uplift in the context of the regional geologic setting. In this article, we follow the terminology of Haugerud (2004) and use the terms "North Cascades," or "North Cascade Range" to refer to the sector of the Cascade Range north of Snoqualmie Pass. We also refer to Haugerud's (2004) High and Western Cascades south of Snoqualmie Pass but still within Washington State as the "southern Cascades," or "southern Cascade Range," although both the High and Western Cascades extend south into Oregon and California (fig. 1B). Similarly, when we refer to the "Cascades," or, "Cascade Range," we refer to the combined northern and southern portions of the range in Washington State.

Early geologic investigators of Washington State (for example, Russell, 1900; Willis, 1903; Smith, 1903) pondered how and when the Cascade Range became the topographic feature observed today. Not surprisingly, models for the topographic development of the range evolved significantly over the past century. Due to the presence of a regionally widespread Miocene marker unit, the extensive Columbia River Basalt (CRB), much of the analysis of Cascade topographic history has focused on post-Miocene topographic evolution, as we do here. However, a wide range of conflicting interpretations has been offered to explain the topographic history of the Cascades. The earliest hypothesis proposed that the entire region forming the Cascade Range in Washington was a low-relief surface (peneplain) at the start of the Miocene that was subsequently uplifted to its current altitude in the past 10 to 15 My (Russell, 1900; Smith, 1903). A second hypothesis suggests that a mountain range already formed a topographic barrier along nearly the entire length of Washington at the start of the Miocene. In this hypothesis, the Miocene Cascade Range funneled the Columbia River Basalt through the Columbia River gorge in the far southern part of the state, and sustained additional uplift after the emplacement of the basalt (for example, Reidel and others, 1989). A third hypothesis combines elements of the previous two, suggesting that whereas the northern portion of the range stood in relatively high relief at the start of the Miocene, the low-relief southern part only became a mountain range after renewed post-Miocene uplift raised the entire region (Mackin and Cary, 1965). These conflicting interpretations of the topographic evolution of the range remain unresolved.

We further discuss and then evaluate the three hypotheses for the physiographic development of the Cascade Range using several new data sets: 1) digital topographic data from a new 10-m grid digital elevation model (DEM), 2) digital 1:100,000 scale geologic maps, and 3) exhumation rate data from apatite (U-Th)/ He (AHe) thermo- 

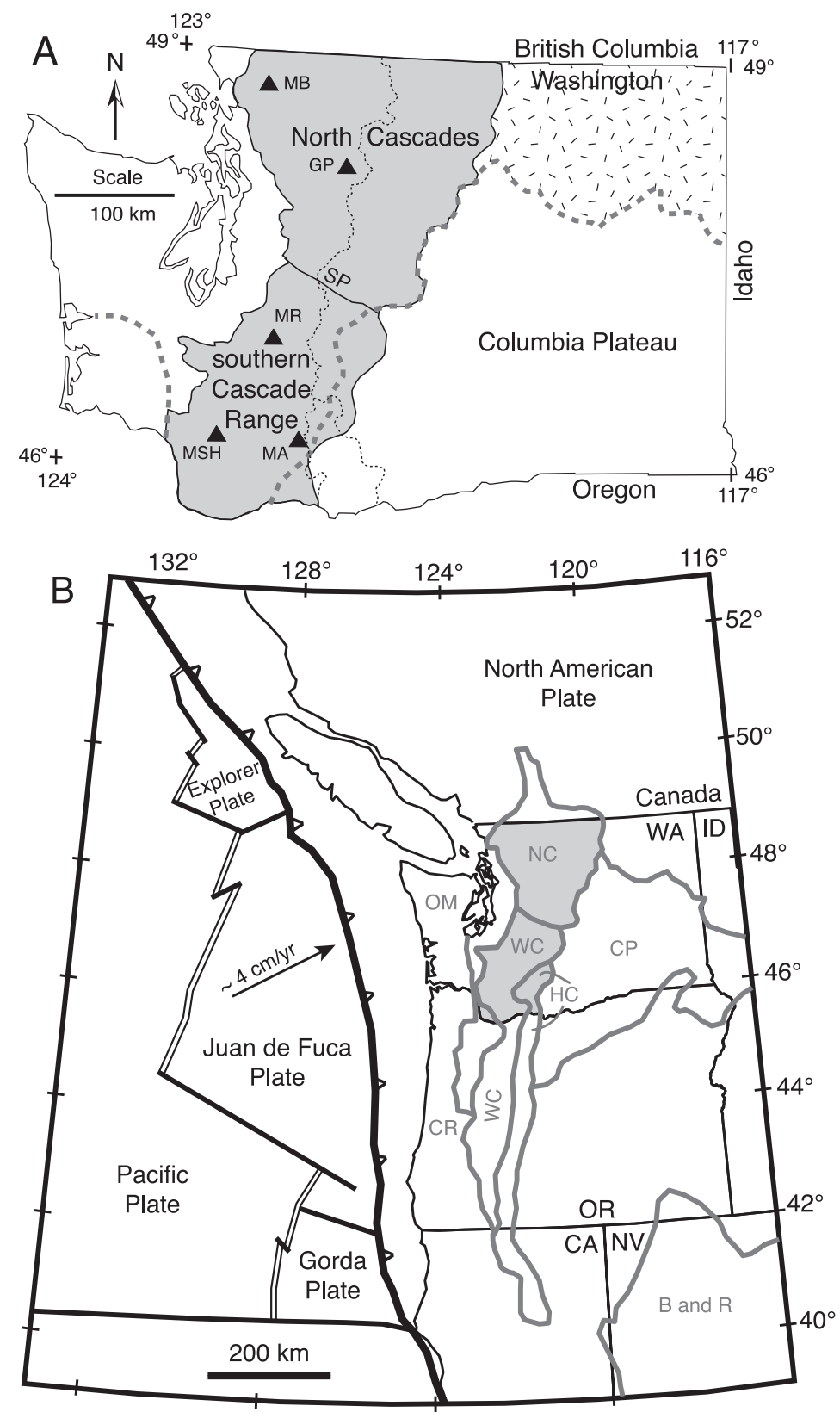

Fig. 1. (A) Physiographic and generalized geologic map of Washington State. "North Cascade" and "southern Cascade Range" areas (from Haugerud, 2004) are shaded in gray and Snoqualmie Pass (SP) noted. The drainage divide is the fine dashed black line, and the generalized outcrop limit of the Grande Ronde Basalt is shown as the dark gray dashed line. The hatchured region shows the exposed pre-Paleogene crystalline core of the North Cascades and northern Washington. Quaternary volcanoes Mt. St. Helens (MSH), Mt. Adams (MA), Mt. Rainier (MR), Glacier Peak (GP), and Mt. Baker (MB) are indicated by the triangles. (B) Generalized tectonic map of the Pacific Northwest. Physiographic provinces from Haugerud (2004) outlined in gray include: North Cascades (NC), Western Cascades (WC), High Cascades (HC), Columbia Plateau (CP), Olympic Mountains (OM), Coast Ranges (CR), and Basin and Range (B and R). Note that the area shaded in gray is the same as in figure 1A. Tectonic boundaries include spreading centers (double line), transform faults (solid lines), and the Cascadia subduction zone (heavy black line with teeth). 
chronometry (Reiners and others, 2002, 2003). We then discuss how our new topographic analysis supports the model for polygenetic topography and suggest how this hypothesis reconciles previous, contradictory interpretations based on regional observations. Finally, we propose a hypothesis for why the topographic differences between the North Cascades and southern Cascade Range are relatively subtle, given their disparate geologic and topographic histories.

\section{PREVIOUS WORK}

The long-running discussion regarding the topographic evolution of the Cascade Range follows general trends in the development of geomorphic thinking. Early workers focused on the deformation of basalt flows and inferred erosion surfaces (Russell, 1900; Willis, 1903; Smith, 1903). Paleobotanical evidence of changing climate due to the development of an orographic barrier was also brought to bear on the question (Chaney, 1938, 1959; Smiley, 1963; Leopold and Denton, 1987). Geomorphologists who worked in the Cascades for years proposed scenarios that summarized decades worth of research and observations (Mackin and Cary, 1965). In the past couple decades, localized studies of deformation of sedimentary units (Swanson, 1997; Cheney, 1997) and isotopic evidence of climate change (McDaniel and others, 1998; Takeuchi and Larson, 2005) entered the debate. Recently, apatite (U-Th)/He dating illuminated the Cenozoic exhumation history of the Cascades (Reiners and others, 2002, 2003). However, because many of these previous investigations focused on a relatively small region, or did not address surface uplift, there is currently no modern, comprehensive analysis on the Cenozoic topographic development of the Cascade Range in Washington State.

\section{Evidence for Post-Miocene Uplift of a Low-Relief Initial Topography}

Compelling evidence for significant post-Miocene surface uplift of the Cascade Range is the deformation of the 17 to 15.5 My Grande Ronde member of the Columbia River Basalt (CRB) on the eastern flank of the range (for example, Russell, 1900; Smith, 1903; Willis, 1903). The CRB is a thick sequence of flood basalts, the majority of which were deposited in extensive, horizontal sheets (Reidel and others, 1989). On the eastern flank of the range, these basalt flows now rise up westward toward the crest of the range. These tilted basalts are so distinctive that before Russell began to map the geology of the Washington Cascades in the 1880s, the prevailing opinion was that the range consisted primarily of tilted basalt flows (Russell, 1900).

Russell's work on the topography and uplift of the Cascades focused on the tilting of the CRB, which were recognized as of Miocene age based on fossils found in interbedded sedimentary units (Russell, 1900), and on the intriguing concordance of peak heights across the range-many peaks rise to similar altitudes as surrounding peaks, with only the young volcanoes extending above the general trend of peak altitudes. Russell proposed that the "surface" formed by the non-volcanic summits represented the uplift of a low-relief erosion surface, or peneplain, into a broad, flat tableland that was subsequently dissected into the steep peaks seen today. In his view, the warping of the CRB on the eastern flank of the Cascades and the modern continuity of peak heights implied post-Miocene uplift from a low-relief erosion surface to a $>2000$ m-high plateau subsequently incised to form the modern topography, with the current peaks defining the uplift and deformation of the original surface.

Russell's successor, George Otis Smith, also pondered the concordance of peak heights in the Cascade Range and commented that in the core of the range and to the west, the peaks are all very sharp, the concordance far from perfect, and there are no identifiable "erosion surface" remnants in the crest or western parts of the range as there are on the eastern flank. Smith also was interested in the timing and character of the deformation of the CRB, and how that deformation related to the formation of the 
Cascades. He identified a series of flat, non-basalt surfaces that he considered remnants of an erosion surface on the east side of the range. Tilted in a similar manner to the basalts, Smith interpreted these surfaces as evidence of a low-relief phase of topography prior to the most recent uplift (Smith, 1903). Smith noted that the deformation of both the low-relief surfaces and the basalt is complex; for example, east of the range, the basalt has been folded into a series of dramatic E-W-trending anticlines in addition to the broader warping on the Cascade flank. More recently, S.C. Porter (1976) suggested that Smith's non-basalt, beveled surfaces represented a pre-basalt erosion surface that was once covered, and perhaps protected, by basalt that was subsequently stripped off. Hammond (1988) also described evidence for a beveled erosion surface, later uplifted to form the Cascade Range.

In addition to physiographic interpretation, paleobotanical evidence favoring the formation of a strong orographic barrier (rainshadow) during the Miocene also provides data for the timing and rate of topographic development of the range. Chaney (1938) noted the change from mesic to xeric flora during the Miocene in sedimentary deposits east of the Cascades in California, Oregon, and southern Washington. Early in the Cenozoic, moisture-dependent trees such as redwoods and sequoias grew throughout the Pacific Northwest, including regions now well east of the Cascade Range where post-Miocene formations lack fossils from moisture-loving ecosystems. Today, the sagebrush ecosystem east of the Washington Cascades is adapted to a continental climate with hot, dry summers and cold winters. Chaney (1938) attributed this climatic transition to the development of a regional rainshadow during uplift of the range.

As a student of Chaney, Smiley (1963) investigated paleoecological changes on the east side of the Cascade Range using plant fossils of the Ellensburg Formation, a deposit that forms a discontinuous sediment apron along the east side of the range in and south of the Yakima River Valley. Smiley suggested that this sediment apron formed during relatively rapid surface uplift of the range. The source material for the Ellensburg appears to be a few isolated, high-volume volcanic centers located near what is now Snoqualmie Pass in the central portion of the range (fig. 1A) (Smiley, 1963; Smith, 1988; Smith and others, 1989). Fluvial and mass-wasting processes moved this volcanic debris eastward as the range was uplifted, and it became interfingered with the west-flowing CRBs. Plant fossils preserved in this subaerial depositional environment show a change in flora from moist conditions in the early Miocene to xeric conditions by the late Miocene. That the sedimentary deposits are finer grained in the early Miocene than in the later Miocene suggested to Smiley (1963) that the topography became steeper through time, enabling the rivers to move larger and larger sediment clasts. Later, Leopold and Denton (1987) also used paleobotanical evidence to show that the Columbia Plateau (the area east of the southern Cascade Range; fig. 1) remained climatologically "open" to the west until $\sim 8 \mathrm{My}$ ago, at which time the uplift of the range and subsequent rainshadow development caused a progressive change from "mesic, summer-wet to xeric, summer-dry" flora (Leopold and Denton, 1987: p. 848).

More recently, isotopic evidence from eastern Washington further supported the hypothesis of rainshadow formation during the Miocene. Orographic barriers tend to cause depletion in the $\delta^{18} \mathrm{O}$ of precipitation on the leeward side of the range (Chamberlain and Poage, 2000). Takeuchi and Larson (2005) show that depletion of ${ }^{18} \mathrm{O}$ in soil samples from eastern Washington indicates that the rise of an orographic barrier began ca. 16 My ago and continued steadily until 4 My ago. These recent isotopic data are consistent with the paleobotanical evidence for the development of a rainshadow during the middle Miocene. 
Researchers have also investigated the uplift of the Cascade Range in Washington by studying structures and tilting in sedimentary deposits on the east side of the range. Swanson (1997) studied volcanic deposits along the Tieton River, an east-flowing river that drains part of the southern Washington Cascades, and found 3 My-old fluvial deposits that now have a significantly steeper dip than the modern river. Swanson concluded that this difference in dip indicates tilting of the deposits after $3 \mathrm{My}$, resulting from differential uplift in the center of the range. Cheney (1997) suggests that deformation of the 3-My-old Ringold Formation of central Washington, east of the range, also implies significant post-Pliocene uplift of the Cascade Range.

Finally, small exposures of 15.6-My-old Grande Ronde Basalt (GRB) near the crest of the range hint at a once-greater, and possibly continuous, areal extent over southwestern Washington. Hammond and others (1992) describe Steamboat Mountain, a 1630-m-high promontory with $380 \mathrm{~m}$ of GRB at its top, located $\sim 10 \mathrm{~km}$ west of Mt. Adams and about $1 \mathrm{~km}$ west of the modern drainage divide (fig. 1A). Hammond and others (1992) suggest that the basalt of Steamboat Mountain represents either an embayment of GRB into the pre-existing volcanic arc (which would have formed localized peaks), or an intravalley flow, extending east to west across much of the arc. In either case, this outcrop demonstrates that portions of the basalt flowed, at least locally, well into the Cascade arc and westward beyond the modern drainage divide of the range.

\section{Evidence for High Miocene Topography}

Two main data sets have been used to argue for high topography in the Cascade Range during the Miocene: 1) the stratigraphy, structure, and extent of the CRB, and 2) the sedimentology of pre- and syn-CRB sedimentary deposits now also found on the southern east flank of the range. A central inference running through late $20^{\text {th }}$ century CRB literature is that the basalt was "ponded" against a Miocene Cascade Range (sometimes referred to as the "Ancestral Cascades" or, in southern Washington, the Western Cascade Range), and flowed to the Pacific Ocean and other parts of western Washington through the 60-km-wide westward outlet of the Columbia River valley, a persistent structural trough between the Washington and Oregon Cascades (Beeson and Tolan, 1989; Reidel and others, 1989). The primary evidence that basalt ponded against the eastern flank of the range is the macro-scale thinning of the basalt against that flank and non-horizontal contacts of basalt with underlying rocks (Anderson and Vogt, 1987; Reidel and others, 1989). There is also a suggestion that basalts extending beyond the main margin were originally narrow valley deposits and now represent inverted topography (Hammond and others, 1992). In this view, the thinning of basalt flows towards the crest of the Cascades implies that the basalt was essentially "filling the bathtub" of the Columbia Basin, and that narrow tongues of CRB entered the range through deep valleys in a pre-existing southern Cascades (Campbell, 1988). These basalts, being more resistant to erosion than the surrounding rock, now form ridges. These interpretations imply that the CRB on the eastern flank of the range abuts the edge of a pre-existing Cascade Range and that the current boundary of the basalt is a depositional one that does not differ significantly from the extent of the Miocene range.

Evidence for significant Miocene Cascade Range relief is also found in the Ellensburg Formation, a Miocene sedimentary unit that interfingers with and caps the CRB flows on the east flank of the range. The Ellensburg Formation, as noted above, consists of a large volume of fluvially transported, primarily volcaniclastic sediment derived from the west (Schmincke, ms, 1964; Smith and others, 1989). The center of volcanism appears to be near the crest of the central Cascades, and this sediment must have traveled downslope to sedimentary basins in eastern Washington (Smith, 1988). Formations stratigraphically and compositionally analogous to the Ellensburg, such as 
the coarse, fluvially deposited Mashel Formation, found over $50 \mathrm{~km}$ away on the west side of the Cascades, suggest that these volcanic centers could have been quite extensive and had significant relief. Relatively rare plutonic and metamorphic clasts have been attributed to two possible origins. Smiley (1963) suggested that these clasts, which appear to be more common in the younger layers of the Ellensburg, were transported from the northwest and thus represent the progressive unroofing or exhumation of the North Cascades. Alternatively, Schmincke (ms, 1964) suggested that these non-volcanic clasts were transported by an ancient Columbia River, which drained highlands in British Columbia, Idaho, and eastern Washington, as well as northern Washington. Either interpretation of provenance indicates that the crystalline core of northern Washington (now the North Cascades) was exposed and had enough relief to generate and then fluvially transport cobble-sized clasts toward the east.

Textures within the CRB flows also suggest pre-existing east-sloping topography in the Cascade region. Reports of palagonite, basalt deltas, and water-quenched pillow structures have been interpreted as indicating that the basalt flowed into standing water in some locations and to suggest that east-flowing rivers on east-dipping topography were blocked by the encroaching basalt sheets (for example, Mackin and Cary, 1965; Summers, ms, 1976). Mackin and Cary (1965) schematically show a series of basalt-dammed lakes located adjacent to the North Cascades during the Miocene.

\section{Hypothesis of a Polygenetic Origin}

The two models of physiographic development appear mutually exclusive; one invoking topography high enough to block the flows of CRB from the east $>15.5 \mathrm{My}$ ago, the other indicating the lack of an orographic barrier (and thus no mountain range) until after this time. However, J. Hoover Mackin proposed a hybrid model in an underappreciated retrospective essay written for a general audience (Mackin and Cary, 1965). According to Mackin and Cary (1965), the Cascade Range south of Mt. Rainier was a low-relief, low-elevation plain that was inundated and covered by the CRB, with isolated volcanoes near the modern range crest supplying volcaniclastic debris to deposits such as the Ellensburg Formation. During this same time, however, the northern Cascades already stood as a "somewhat rougher landscape on granitic rocks," and were already at least a kilometer high when the basalts were erupted (Mackin and Cary, 1965). Both northern and southern Cascades subsequently experienced rock uplift in excess of erosion, causing surface uplift and the tilting of the basalts on the range flank. As discussed further below, we argue that this view is most consistent with the Miocene rainshadow development, the deformation of the basalts, the apparently deeper-exhumed rocks of the north Cascades, and the topographic analyses we present here.

\section{METHODS}

Our investigation focuses on DEM analyses using a new 10-m-grid DEM of Washington State and combining such analyses with geologic and exhumation rate data (Reiners and others, 2002, 2003). First, we measured several geomorphic parameters throughout the range to characterize the topography and constrain the differences in the morphologies of the northern and southern parts of the range. Using GIS, we analyzed the extent and spatial pattern of uplift in the Grande Ronde member of the CRB. To determine the spatial variation in the proportion of the modern elevation of the range attributable to post-Miocene uplift, we evaluated latitudinal gradients in the local elevation maxima of the CRB and compared them to the elevation of the range as a whole. We also investigated the spatial relationship of the CRB relative to the eastern flank of the range and the modern drainage divide. Finally, we compared exhumation rates estimated from published apatite (U-Th)/He cooling ages between 


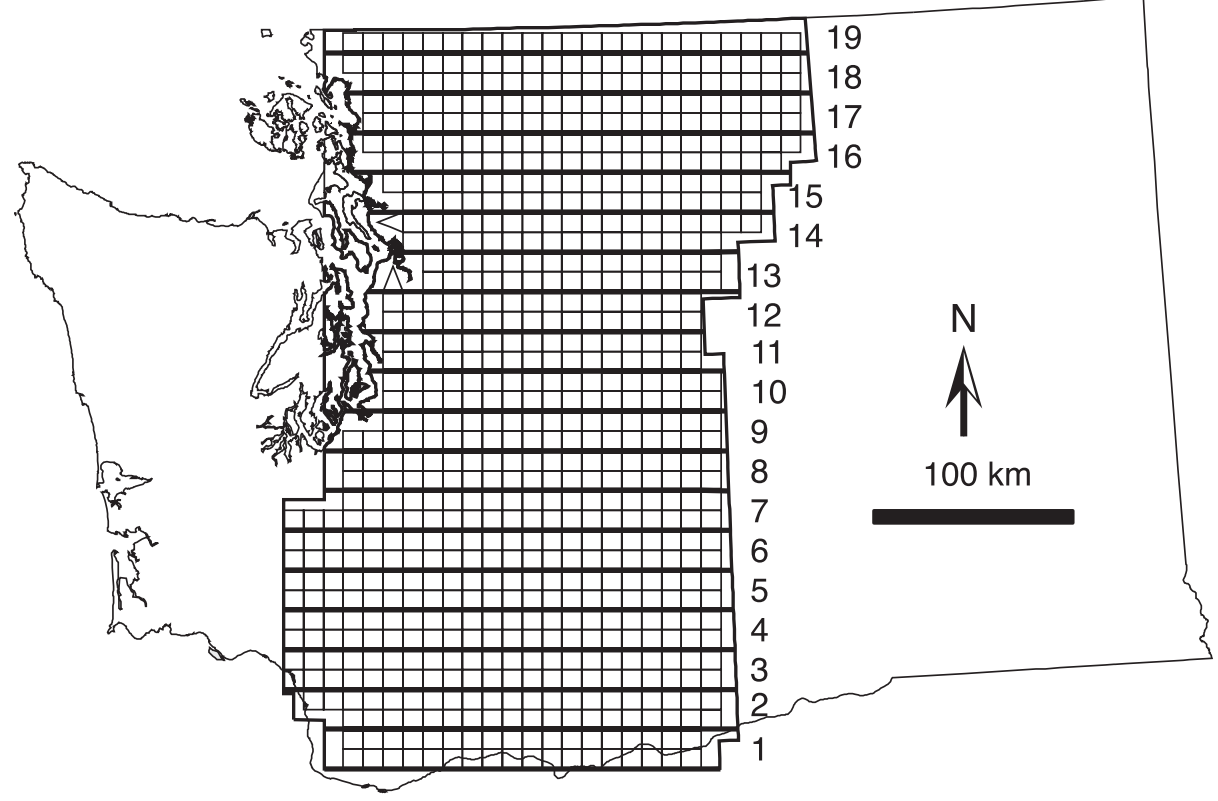

Fig. 2. Analysis windows for topographic calculations. Bold horizontal lines show the position of "swaths" used to make topographic profiles, numbers on the right indicate the swath number. Fine lines show the position of $100 \mathrm{~km}^{2}$ windows used for morphometric analyses.

the northern and southern Cascades to evaluate proposed hypotheses regarding the post-uplift erosion of the range.

\section{Topographic Analysis of the Cascades}

Peaks in the North Cascades generally rise to higher altitudes and appear steeper than the southern Cascade Range, but to our knowledge no modern morphometric techniques based on analysis of DEMs have been employed to quantify such distinctions. Thus, we used GIS and statistical analyses to determine whether the topography of the North Cascades and southern Cascade Range in Washington State are now demonstrably distinct from each other, and if so, in what manner. We used the 10 by 10 $\mathrm{m}$ grid size DEM of the Cascades, constructed from 7.5-minute USGS topographic quadrangles, to investigate patterns in the mean and maximum elevations, slope, and relief of the range. Because the underlying geology is a potential factor in determining topography, we divided the range into northern and southern regions based on the southern limit of the exposed crystalline core, which is approximately the latitude of Snoqualmie Pass (fig. 1). This division between North and southern Cascades corresponds to Haugerud's (2004) delineation of physiographic provinces. Due to orographic effects, the west side has considerably higher precipitation than the eastern side. Because precipitation is also a potential factor in controlling or modifying the topography of the range (for example, Reiners and others, 2003), we further subdivided the study area into regions east and west of the drainage divide (fig. 1, dashed line).

To understand how maximum and mean elevations, relief, and slope vary across the range from both south to north and east to west, we first divided the area of the DEM indicated in figure 1 into 10 by $10 \mathrm{~km}$ analysis windows (fig. 2). Within each 100 $\mathrm{km}^{2}$ area, we determined the maximum and minimum elevations and calculated the 
relief using standard ArcInfo commands. While relief is highly dependent on the area used for the calculation, we are interested primarily in how relief differs with latitude, not the magnitude of the relief itself. Therefore, we use the same analysis window size across the range. By using 10 by $10 \mathrm{~km}$ analysis windows, subtracting minimum from maximum altitudes approximates the ridge-valley relief (for example, Montgomery and Greenberg, 2000). We also found the mean elevation within each analysis window. We determined the average slope within analysis windows by taking the average of slopes calculated for each 10 by $10 \mathrm{~m}$ cell within the window, as determined from the eight nearest neighbors. After each of these parameters (maximum altitude, mean altitude, relief, and mean slope) was found for each 10 by $10 \mathrm{~km}$ window, we did a Kolmogorov-Smirnov test on the values for several $10 \mathrm{~km}$-wide rows to determine if the data are normally distributed with respect to latitude. We then determined the mean and $1 \sigma$ standard deviation of each of these parameters across the $10 \mathrm{~km}$-wide W-E rows. To explore topographic distinctions between the eastern and western sides of the Cascade Range, we also split each W-E row at the drainage divide and calculated the mean and standard deviation of each of the topographic parameters for the two sides of the range.

We then employed two statistical measures to illustrate distinctions between the topography of the North and southern Cascades. To determine whether they are statistically distinct, we did a Student's t-test (2-tailed distribution, equal variance) on the northern and southern populations (combined and separated eastern and western flanks) of each morphometric index. If there were distinctions in a morphometric index, we then assessed whether the latitudinal change across the range was linear or had some other shape by calculating the least-squares linear regression of each index, using latitude as the independent variable, for the entire N-S data set. We then determined the linear least squares regression for southern and northern regions separately and compared them to the regression on the full data set. On one extreme, if the two separated regressions are indistinguishable from a linear trend encompassing the entire N-S span of data, that morphometric index does not reflect the transition from southern to North Cascades, even if a t-test indicates that index is statistically different between those regions. On the other extreme, the morphometric index may show a "break" in topographic characteristics if the slopes of the separate northern and southern regressions differ significantly from the slope of the entire data set.

\section{Spatial and Topographic Patterns of the Grande Ronde Basalt}

We also addressed whether the current boundaries of the CRB are depositional or erosional based on the topographic relationship between the basalt and the range. A geologic map shows that the 17- to 15.5-My-old Grande Ronde Basalt (GRB), one of the earliest and most spatially extensive member of the CRB, currently covers $\sim 150,000$ $\mathrm{km}^{2}$ of Washington, Oregon, and Idaho (Tolan and others, 1989). This basalt flowed outward hundreds of kilometers from source vents in eastern Washington, Idaho, and Oregon. The presence of GRB indicates that an area had relief less than the thickness of the flow that now covers it. While we can confidently assert that all areas now covered by basalt were not what one would call a "mountain range" during the time that the basalt was emplaced, it is more difficult to be definitive about the paleorelief in areas where basalt is lacking. A lack of basalt could either be due to its erosional stripping from an originally low-relief surface, or because the area had enough relief to stand above the basalt flows. We circumvented this ambiguity by investigating the spatial and topographic trends of the basalt relative to the topography.

The GRB has four distinct units based on magnetic polarity; we used the youngest two members of the GRB, N2 and R2, as the marker formations for rock uplift because together they are the flows now found on the eastern flank of the southern Cascades. 


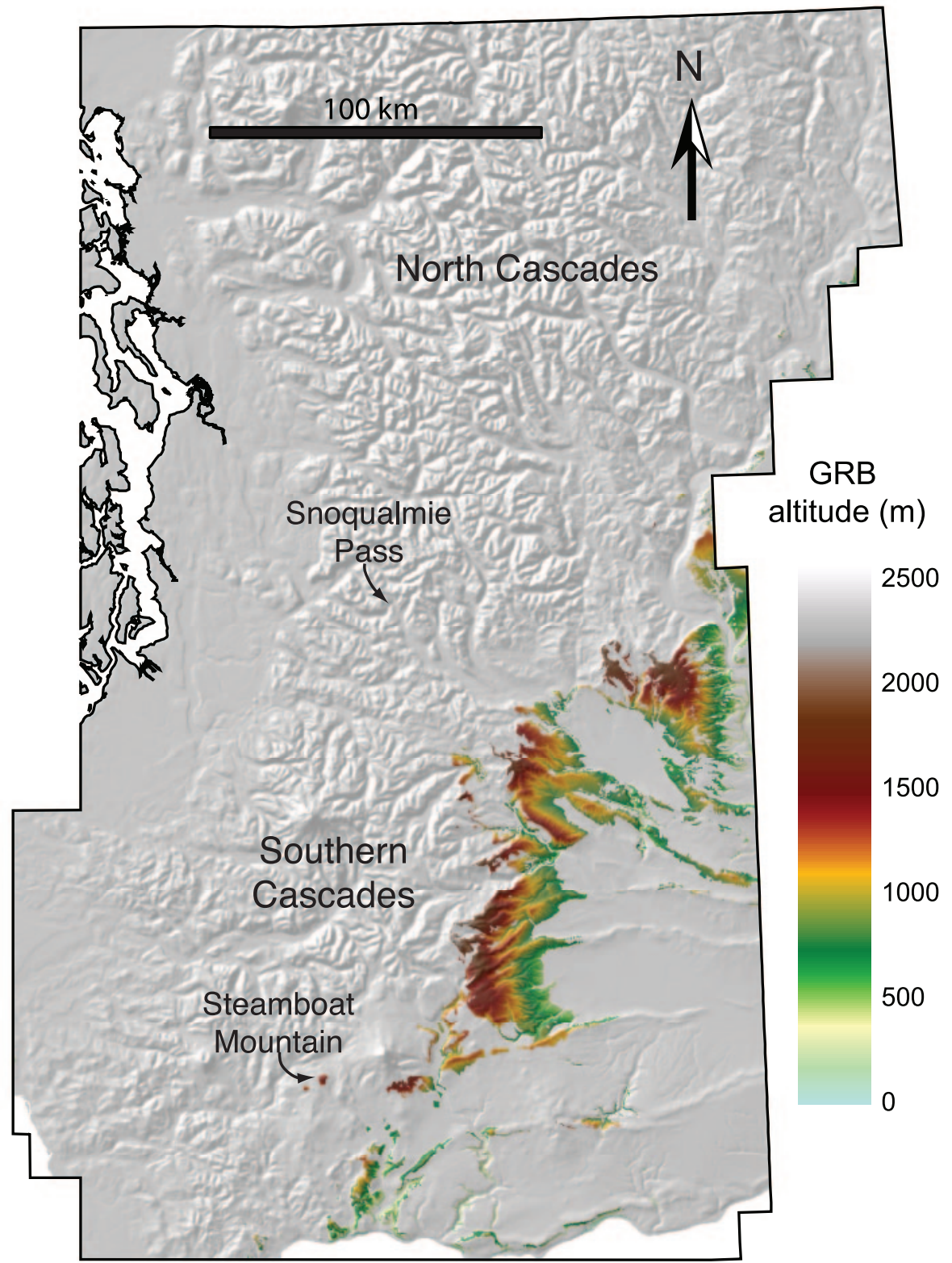

Fig. 3. Altitude of Grande Ronde Basalt (colored) superimposed on top of the shaded relief map (gray) of Washington State. Location of study area within Washington State can be seen in figure 2.

To analyze the topography of the modern basalt surfaces, we created a topographic coverage of these units of the GRB by clipping the 10-m DEM of our study area to the area mapped as this basalt on the 60-minute, 1:100,000-scale digital state geologic map series (fig. 3; Tabor and others, 1982; Frizzell and others, 1984; Walsh, 1986a, 1986b; Korosec, 1987a, 1987b; Phillips, 1987a, 1987b; Phillips and Walsh, 1987; Schasse, 
1987a; Tabor and others, 1987; Gulick and Korosec, 1990a, 1990b; Schuster, 1994a, 1994b, 1994c). Using this new DEM of the GRB, we investigated its topography and the relationship of this topography to that of the Cascades as a whole. Specifically, we investigated west-east trends in GRB elevation within the Cascade Range, the spatial distribution of the modern basalt outcrop relative to the Cascade Range, and trends in the maximum elevation relative to the maximum elevation of the range at the same latitudes.

For several of these analyses, we divided the DEM of the range into nineteen, E-W-trending, 20-km-wide rectangles, or "swaths," oriented orthogonally to the N-S trend of the range (fig. 2). This division of the DEM allowed us to construct a series of $\mathrm{W}$ - to E-oriented topographic profiles and investigate different physiographic trends in the basalt. To construct the topographic profiles across each swath, we developed an ArcInfo algorithm that found the maximum, mean and minimum elevations spanning the $20 \mathrm{~km} \mathrm{~N}-\mathrm{S}$ distance, and at $10 \mathrm{~m} \mathrm{~W}$-E resolution. We then constructed maximum, mean, and minimum topographic profiles for just the areas covered by basalt by running this same algorithm on a DEM of just the GRB. These topographic profiles illustrate the deformation of the basalt and show its location and elevation relative to the non-basalt areas of the range. Assuming the surfaces of the basalt flows were originally horizontal, their topographic relief today constrains the differential rock uplift that occurred since the late Miocene.

We also compared the degree of overlap between basalt and the Cascade Range between the northern and southern regions of our study area to help determine the Miocene paleotopography. For this analysis, we identified the average UTM easting coordinate of the western basalt limit in each 20-km-wide swath, and compared it to the average UTM easting coordinates of the eastern limit of the Cascade physiographic province and the drainage divide within that swath (Haugerud, 2004), as defined using the DEM and shown in figure 1. We also compared the maximum altitude of the basalt to the maximum altitude overall in each swath (excluding Quaternary volcanoes). This analysis allows us to constrain where the western limit of low relief existed relative to the modern crest of the range, and to determine if this relationship varies south to north. For example, areas that had low paleorelief near the axis of post-Miocene uplift would allow the GRB to encroach close to that axis. When this area experienced rock and surface uplift, the basalt, if preserved, would now be found at the high altitudes at or near the crest of the range. Conversely, if there were high paleorelief in the location of the uplift axis, the basalt would be blocked some distance from that axis, and preserved basalt would thus be found some distance from the range crest and at lower altitudes.

\section{Exhumation Rates Constrained from Apatite (U-Th)/He Thermochronometry}

We consider north-south trends in the long-term average exhumation rates because it has been suggested that the North Cascades are higher, more deeply exhumed, and lack CRB cover today because they experienced greater late- and post-Miocene uplift and thus greater erosion than the southern Cascades (for example, E. Cheney, personal communication, 2002). Alternatively, the North Cascade Range may now be high, deeply exhumed, and lack CRB cover because this region was already a topographic high during the Miocene and has been experiencing erosional exhumation for a longer time, not at a faster rate, than the south. Apatite (U-Th)/He (AHe) thermochronometric dating measures how long ago a rock passed upward through the $60^{\circ} \mathrm{C}$ geotherm, $\sim 2$ to $3 \mathrm{~km}$ below the surface (for example, Farley, 2002). If one makes the assumption that the exhumation has been constant since that time, it is possible to calculate the long-term average exhumation rate for that area. Using the methods of Brandon and others (1998), these rates were calculated using AHe ages in the Cascades (Reiners and others, 2002, 2003, some unpublished data), geothermal 
gradients from Blackwell (1990), and elevation data from the DEM. We did not use all available AHe data for the Cascade region, as some samples appear to have been reset or otherwise influenced by thermal perturbations (P.W. Reiners, personal communication, 2006). We then determined how long-term average exhumation rates varied with latitude.

RESULTS

The North Cascades and southern Cascade Range in Washington have previously been differentiated primarily on the basis of geology (as for example, by Haugerud, 2004). A glance at generalized geologic maps of Washington State (for example, Weissenborn, 1969; Schuster, 1992) shows that primarily pre-Cenozoic metamorphic and intrusive igneous rocks are exposed north of Snoqualmie Pass, whereas south of Snoqualmie Pass, primarily Paleogene volcanic and sedimentary rocks are exposed. However, the differences in the altitude-derived topographic indices between these two regions are gradational and subtle. In contrast, average slope and relief are more distinct between the northern and southern Cascades. Many of the topographic distinctions between the north and south are less apparent on the western flank of the range than on the eastern flank.

Results of the Kolmogorov-Smirnov tests fulfilled the null hypothesis (K-S > 0.05), indicating that maximum altitude, mean altitude, relief and slope values within 10 by $10 \mathrm{~km}$ windows are all normally distributed within eight randomly-selected cross-range latitudinal bins (we did not test all 34 latitudinal bins for each of the four morphometric indices). Because these values are normally distributed, we then calculated the average and $1 \sigma$ standard deviation of each index across these latitudinal bins. When eastern and western regions of the range are analyzed together, the average maximum altitudes are highest in the northern Cascades $(\sim 2000 \mathrm{~m})$ and decrease linearly to the south $(\sim 1100 \mathrm{~m})$ at a rate about $2.8 \mathrm{~m} \mathrm{~km}^{-1}$ (fig. 4). A Student's t-test (2-tailed distribution, equal variance) comparing the average maximum values of the North and southern Cascades gives a value $<<0.01$, indicating that these populations are in fact distinct. However, there is so little difference in the N-S altitude gradient between the northern and southern parts of the range that least squares linear regressions of the northern and southern regions split at Snoqualmie Pass vary only slightly from the regression encompassing the entire region; there is no "break" in the trend of maximum altitudes as one might expect at the major geologic boundary near Snoqualmie Pass. When divided into eastern and western regions, the average maximum altitudes continue to be distinct populations, and maximum altitudes decrease to the south at a slightly steeper gradient on the eastern flank than on the western flank (fig. $4)$. The $R^{2}$ values are generally lower for the southern Cascades than the North Cascades or the region as a whole because the Quaternary volcanoes rise higher above the landscape in the south.

Average mean altitudes are also highest in the north $(\sim 1200 \mathrm{~m})$ and decrease approximately linearly to the south $(\sim 700 \mathrm{~m})$, although the gradient is lower $(\sim 1.3 \mathrm{~m}$ $\mathrm{km}^{-1}$ ) than it is for the maximum altitudes (fig. 5). As with the maximum altitudes, a Student's t-test indicates that the distinction in mean altitudes between the North and southern Cascades is significant. However, the N-S gradients of mean altitudes of separate northern and southern regions do not differ substantially from the mean altitude gradient of the entire range. When the western flank is analyzed separately, the distinction in mean altitude between north and south is not significant (t-test result: $t=0.16)$, and the linear regression fits the data poorly $\left(\mathrm{R}^{2}<0.50\right.$, fig. 5$)$. On the eastern flank, mean altitudes are distinct between north and south. For both flanks of the range, however, there again is not an obvious "break" in the northward increase of mean altitudes at Snoqualmie Pass. 


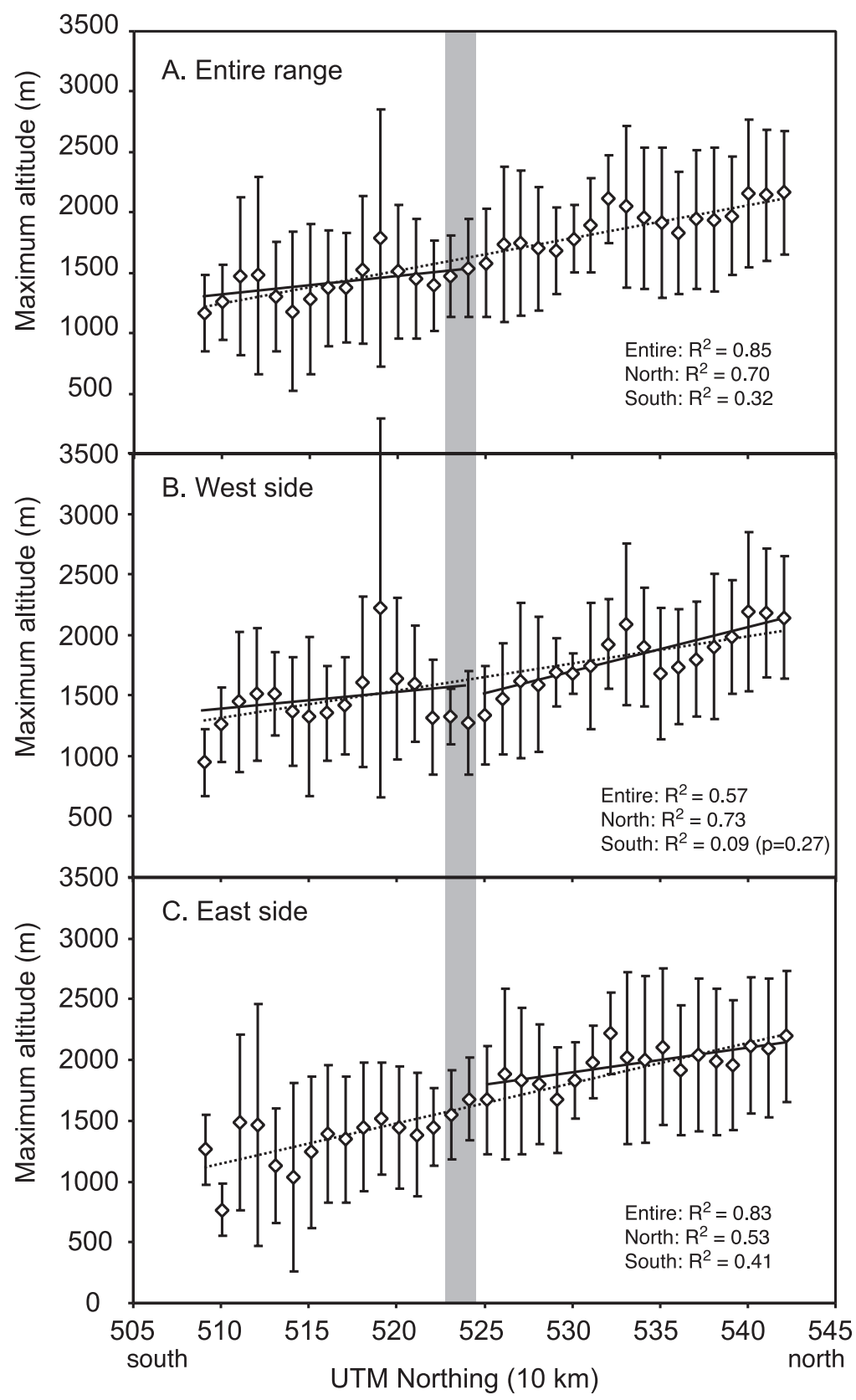

Fig. 4. Maximum altitudes (diamonds) averaged across 10-km-wide latitudinal bins (shown in figure 2) for: (A) the entire range; (B) west of the range crest; and (C) east of the range crest. Error bars indicate $1 \sigma$ standard deviation. The vertical gray bar denotes the approximate latitude of Snoqualmie Pass, dividing the range into northern (right) and southern (left) regions. Least squares linear regressions for the average maximum altitude for the entire (dashed line), northern (solid line), and southern (solid line) areas of the range are also shown. Note that if the regression for a subregion is identical to the regression for the entire region, only the latter is shown. All p-values are $<0.01$ unless noted. 


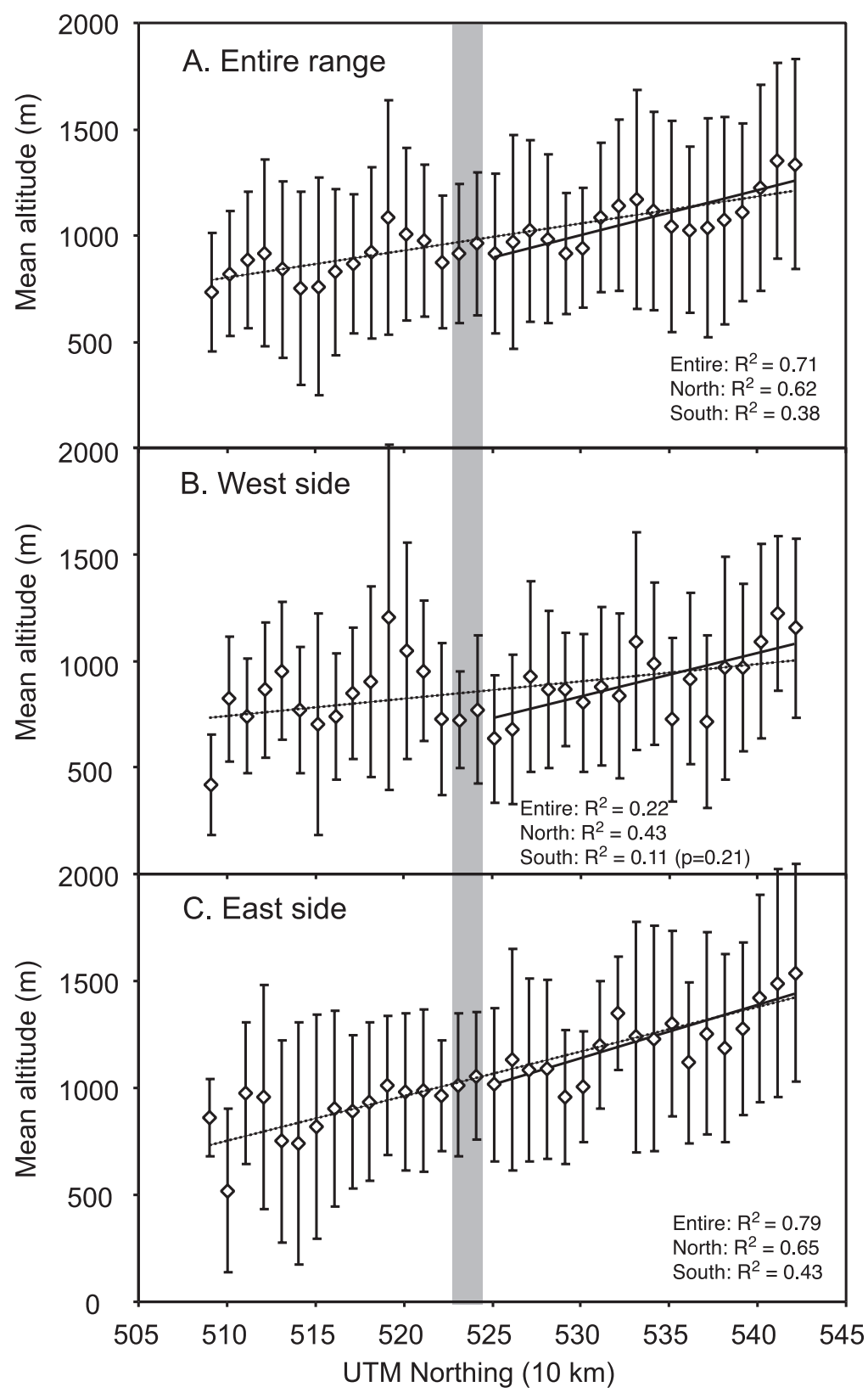

Fig. 5. Mean altitudes (diamonds) of 10-km-wide latitudinal bins for: (A) the entire range; (B) west of the range crest; and $(\mathrm{C})$ east of the range crest. The vertical grav bar denotes the approximate latitude of Snoqualmie Pass. Error bars indicate $1 \sigma$ standard deviation. Least squares linear regressions for the average altitudes for the entire (dashed line), northern (solid line), and southern (solid line) areas of the range are also shown. If the regression for a subregion is identical to the regression for the entire region, only the latter is shown. All p-values are $<0.01$ unless noted.

As with altitude, a t-test shows that the relief in the north is significantly higher than in the south. Unlike the altitude gradients, the N-S linear regression of mean relief for the entire N-S span of the range is noticeably different than regressions for 
northern and southern regions separated at Snoqualmie Pass, particularly when western and eastern flanks are analyzed separately (fig. 6). In the southern Cascades, the average relief ranges from 750 to $1000 \mathrm{~m}$ and a linear least-squares regression shows that relief does not increase or decrease linearly with respect to latitude (fig. 6). This lack of a statistically significant N-S trend in relief in the south is particularly striking on the west side of the range. North of Snoqualmie Pass, however, relief increases towards the north, with relief reaching $>1500 \mathrm{~m}$ in the northernmost part of the range. On the west side of the northern Cascades, this increase in relief with increasing latitude is strongly linear, with relief increasing from about $800 \mathrm{~m}$ at Snoqualmie Pass to nearly $2000 \mathrm{~m}$ at the Canadian border, at a gradient of $4.9 \mathrm{~m} \mathrm{~km}^{-1}$. On the east side of the range, there is no latitudinal trend in relief $\left(\mathrm{R}^{2}<0.001, \mathrm{p}=\right.$ $0.96)$, with a peak in relief occurring midway between Snoqualmie Pass and the northern border.

The average slopes of E-W trending latitudinal swaths are also generally higher in the North Cascades than in the southern Cascades. The increase in slope from south to north is linear on the west flank of the range, but there is a sharp break in the trend in slopes on the east flank of the range (fig. 7). When both the east and west flanks are considered, the average slope is approximately constant at $\sim 23^{\circ}$ from Snoqualmie Pass to the northern border; when only the eastern flank is considered, there is a decrease in average slope north of Snoqualmie Pass. South of the pass, the average slope is generally less than in the north, ranging from $10^{\circ}$ to $20^{\circ}$, with higher slopes on the western side of the range than on the eastern side. There is also a slight northerly increase in slope in the southern Cascades; this gradient of the slope trend is both steeper and stronger on the eastern side of the range than on the western side.

We have also determined the averages of all the altitude, relief, and slope measurements for the four "quadrants" of the range: northeast, northwest, southeast, and southwest (fig. 8). Maximum and mean altitudes are very slightly higher (and overlap with their $1 \sigma$ standard deviations) in the east than the west in the northern Cascades, and vice versa in the southern Cascades. There is no statistical difference in relief or slope in the northern Cascades between east and west, but both relief and slope are lower on the east flank than the west flank in the southern Cascades.

\section{Spatial and Topographic Patterns of the Grande Ronde Basalt}

Topographic profiles show the deformation of the Grande Ronde Basalt (GRB) on the east flank of the Cascades (fig. 9). In the southernmost swaths (1-10), the upper surfaces of the N2 and R2 GRB flows extend up and westward to the altitude of the range crest, and in places, have crossed the modern drainage divide. The extent of the basalt in the south relative to the edge and crest of the range stands in stark contrast to the North Cascades (swaths 11-15) where the basalt is limited to the eastern edge of the range. No N2 or R2 GRB is exposed in swaths 16 through 19.

CRB exposures are higher in southern Cascade swaths in both altitude above sea level and as a percentage of maximum swath altitude. The highest basalt in the southernmost swaths is found at $\sim 1500 \mathrm{~m}$, increasing to $\sim 2000 \mathrm{~m}$ in swaths 5 through 10. In each of these southern Cascade swaths, the basalt reaches 80 percent to 100 percent of the highest altitude found in the entire swath, excluding the Quaternary volcanoes (fig. 10). For example, in swath 6 , the highest point in the swath $(2100 \mathrm{~m})$ is an exposure of N2 GRB. Conversely, the highest basalt in the North Cascades (swaths $11-15$ ) is at $1500 \mathrm{~m}$, decreasing to $<1000 \mathrm{~m}$ in the northernmost swaths. In addition, these basalt exposures reach a smaller percentage of the total range altitude, only 30 to 60 percent of each swath's highest non-volcanic point. There are no GRB exposures in swaths 16 through 19.

Grande Ronde Basalt exposures are present significantly closer to the crest of the southern Cascades than to the crest of the North Cascades (figs. 9 and 11). In far 


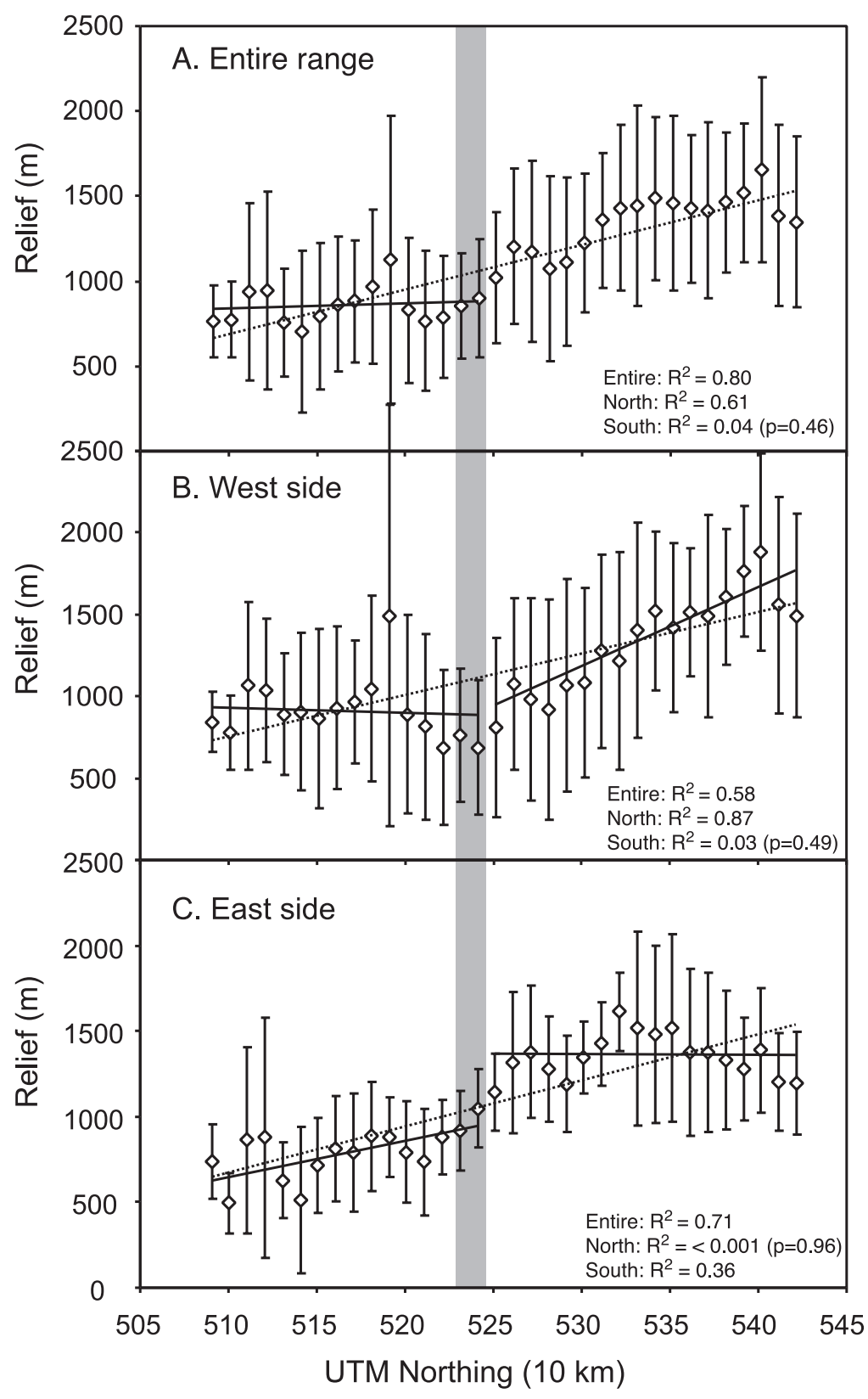

Fig. 6. Mean relief (diamonds) of 10-km-wide latitudinal bins for: (A) the entire range; (B) west of the range crest; and (C) east of the range crest. The vertical gray bar denotes the approximate latitude of Snoqualmie Pass. Error bars indicate $1 \sigma$ standard deviation. Least squares linear regressions for the average relief for the entire (dashed line), northern (solid line), and southern (solid line) areas of the range are also shown. If the regression for a subregion is identical to the regression for the entire region, only the latter is shown. $\mathrm{R}^{2}$ values are indicated for each regression, all p-values are $<0.01$ unless noted. Generally, relief is higher in the north than in the south. There is little trend in relief in the southern Cascades for the range overall and for the west side only; there is a slightly significant linear increase in slope towards the north on the east side of the southern Cascades. Conversely, there is a significant increase in relief in the northern Cascades for the range overall and on the western flank, but no linear trend in relief on the eastern flank. 


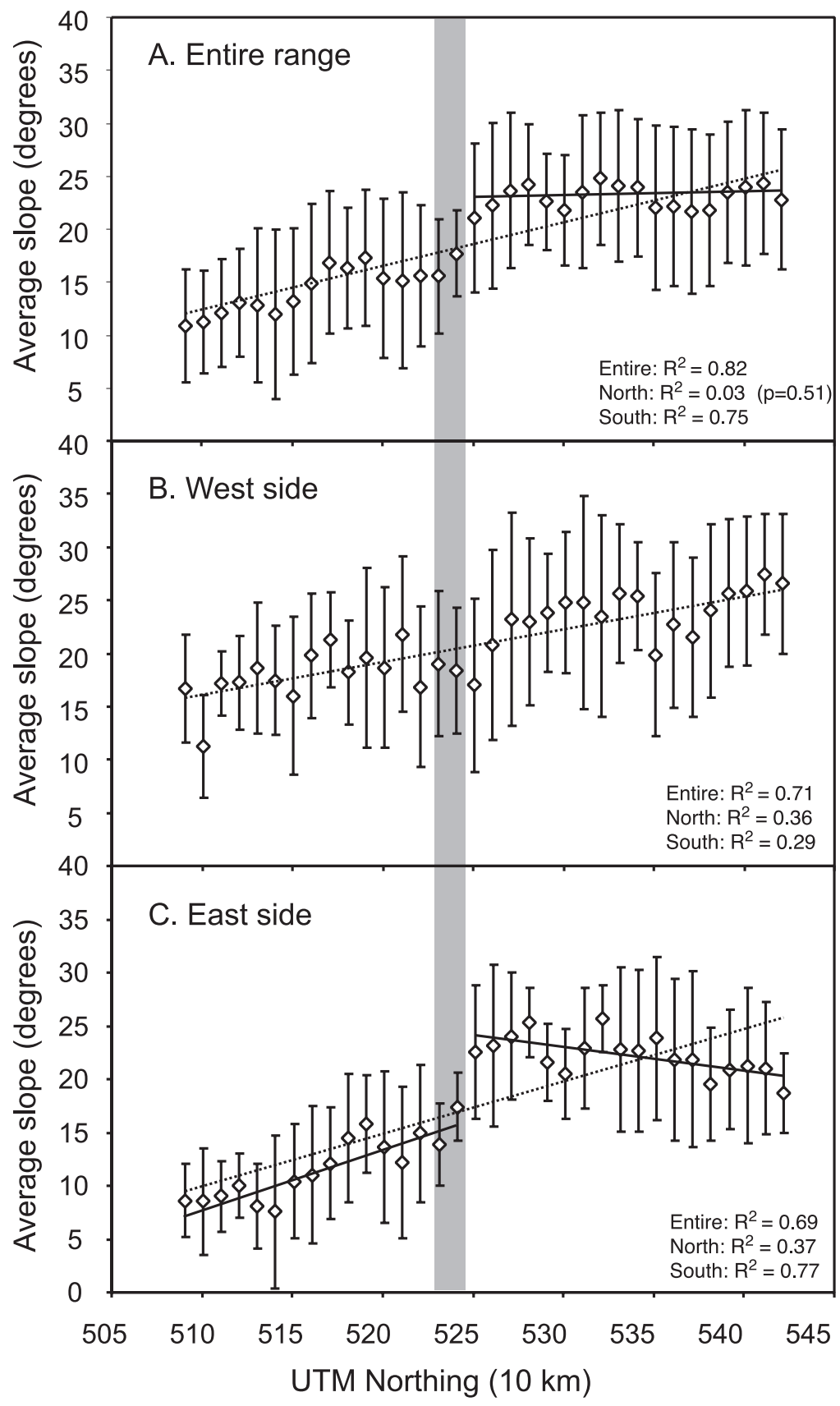

Fig. 7. Average slope (diamonds) of 10-km-wide latitudinal bins for: (A) the entire range; (B) west of the range crest; and (C) east of the range crest. The vertical gray bar denotes the approximate latitude of Snoqualmie Pass. Error bars indicate $1 \sigma$ standard deviation. Least squares linear regressions for the average relief for the entire (dashed line), northern (solid line), and southern (solid line) areas of the range are also shown. If the regression for a subregion is identical to the regression for the entire region, only the latter is shown. All p-values are $<0.01$ unless noted. Average slopes are generally higher in the northern Cascades than in the south, and on the west flank the trend in slopes increases linearly to the north. However, when just the east flank is considered, there is a strong linear increase in slope towards the north in the southern Cascades, then a steep jump in slope at Snoqualmie Pass, then a weakly linear decrease in slopes between the pass and the northern border. 


\section{A. Summary of maximum altitudes}

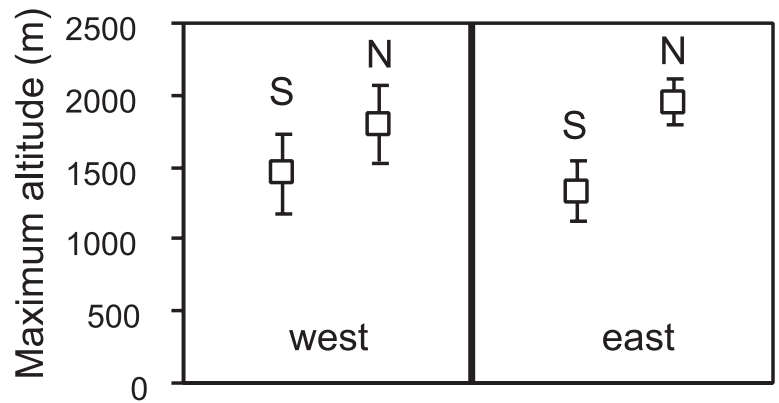

B. Summary of mean altitudes

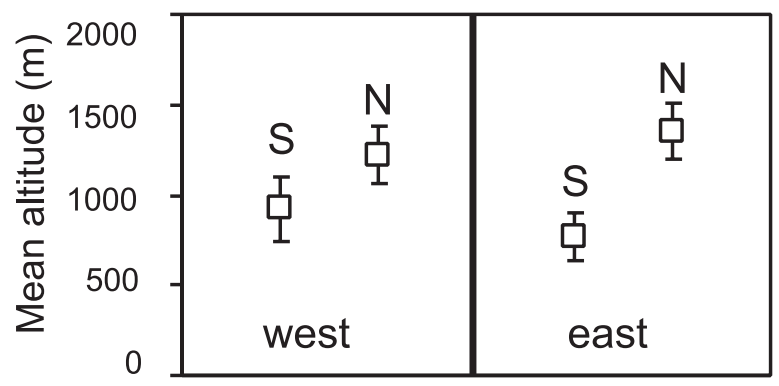

\section{Summary of relief}

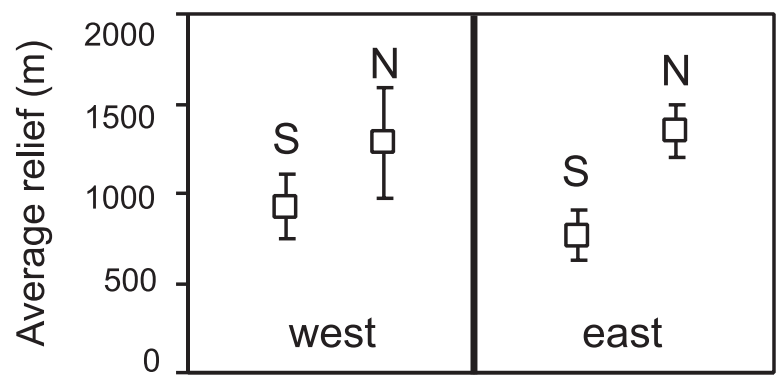

D. Summary of average slopes

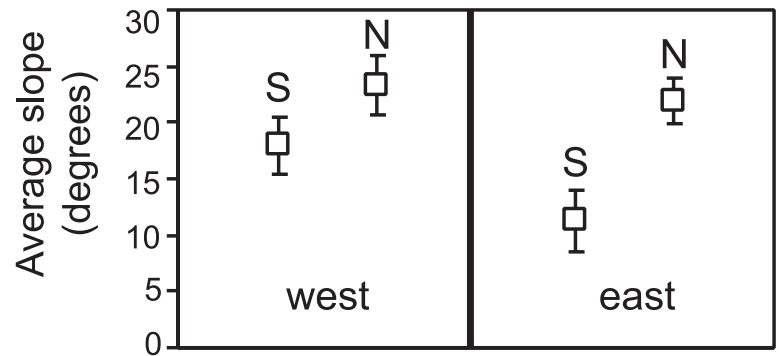

Fig. 8. Summary diagrams showing average values of: (A) maximum altitudes, (B) mean altitudes, (C) relief, and (D) slope for four quandrants of the Cascades, divided W-E by the drainage divide and N-S by Snoqualmie Pass. Error bars indicate $1 \sigma$ standard deviation. There is little overall distinction in any of the topographic parameters between west and east in the northern Cascades. In the southern Cascades, there is little distinction between east and west in altitude or relief, but slopes are significantly lower on the east side than the west side. 


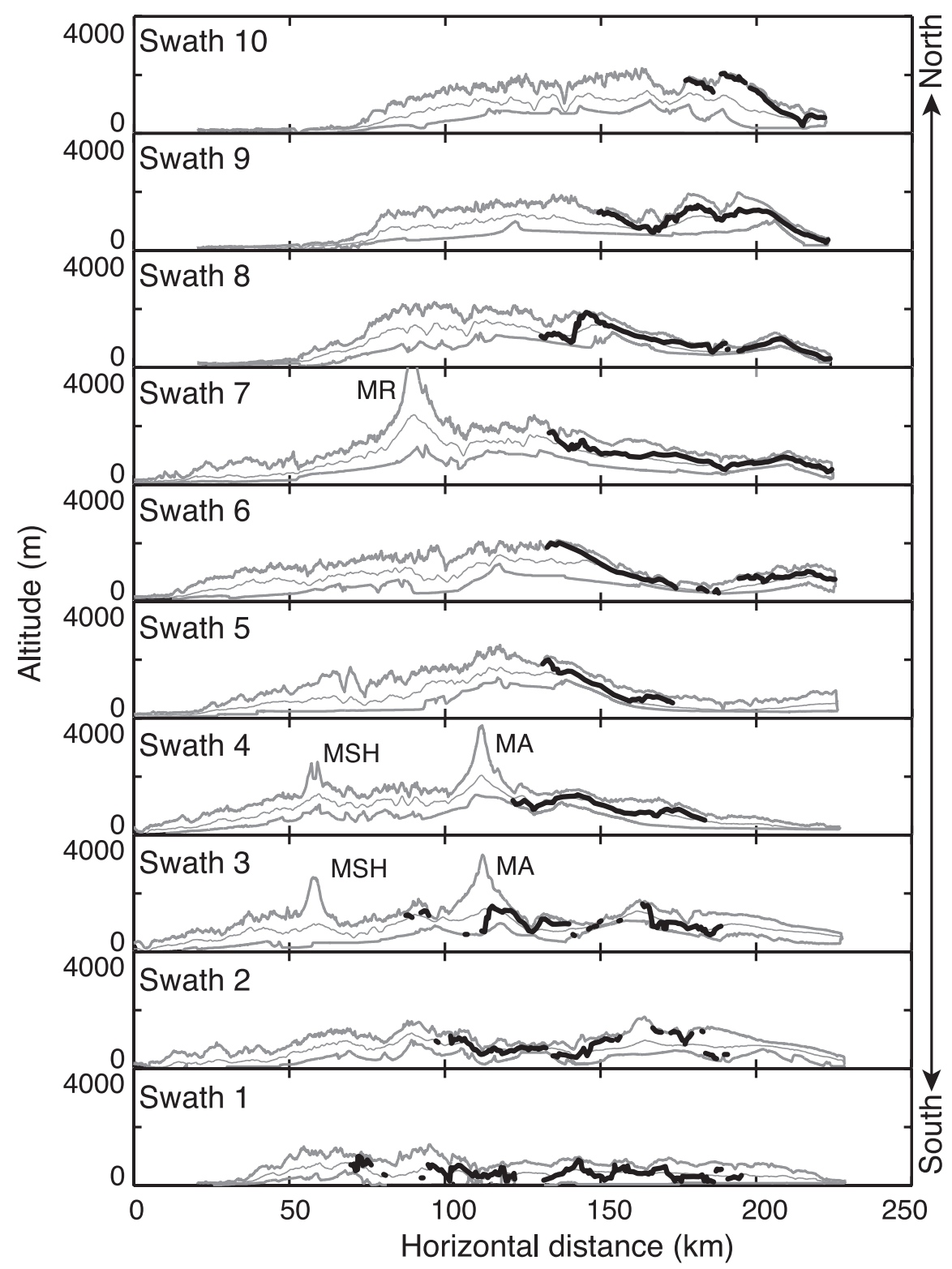

Fig. 9. Topographic profiles across the 19 swaths. Maximum, mean, and minimum topography shown as upper, middle, and lower gray lines, respectively. Upper surfaces of GRB exposures are shown as heavy black lines. The Quaternary volcanoes are labeled as follows: Mount Baker (MB), Glacier Peak (GP), Mount Rainier (MR), Mount St. Helens (MSH), and Mount Adams (MA).

southern Washington (swaths 1 and 3), the basalt is found on the west side of the modern drainage divide, and in swaths 4 through 8 , the basalt has flowed $>50$ percent of the distance from the eastern margin of the range toward the present divide. However, in swaths 11 through 15, the basalt reaches $<10$ percent of the distance between the edge of the range and the divide (fig. 11). 


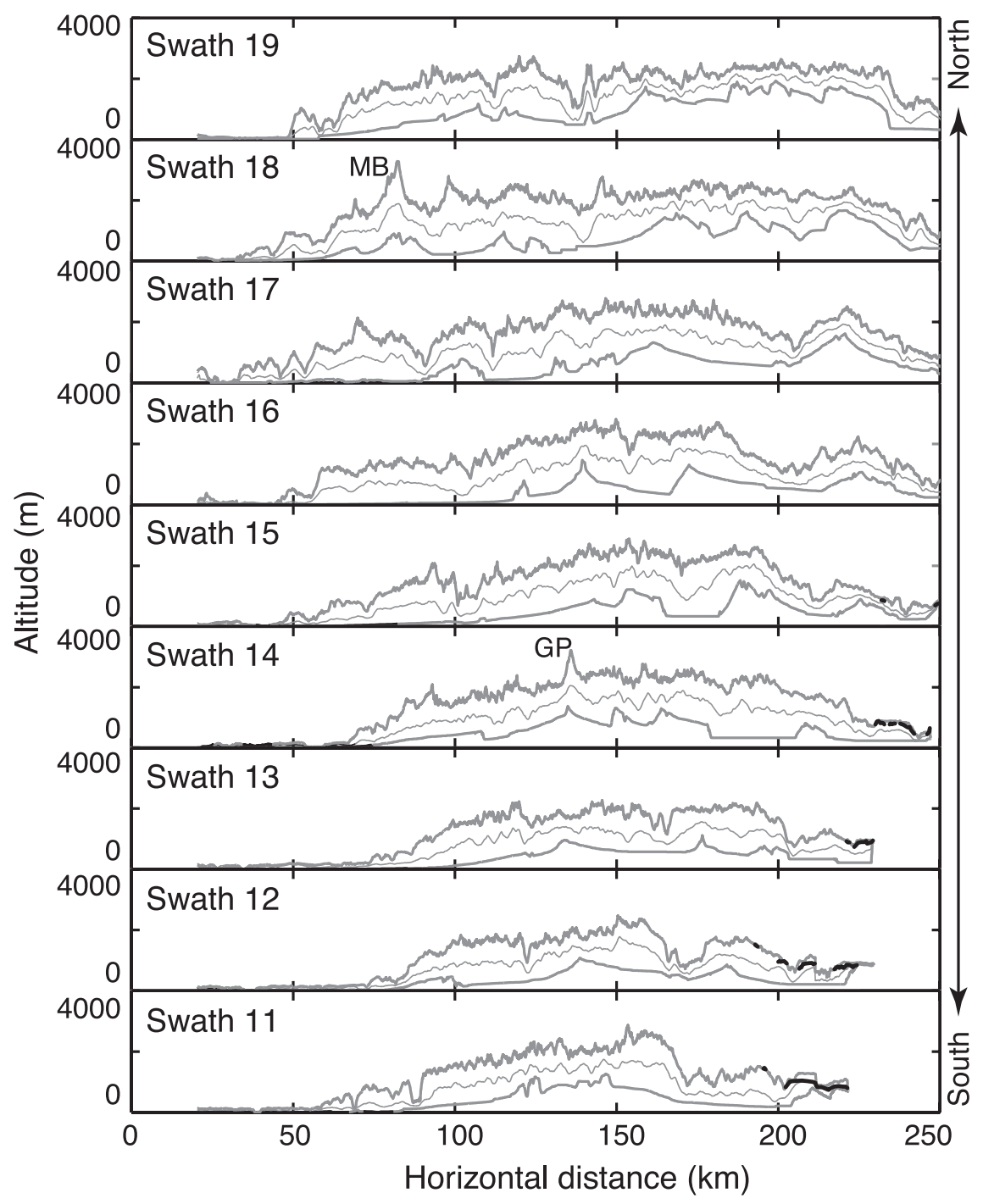

Fig. 9 (continued)

Exhumation Rate Trends from AHe Thermochronometry

The AHe data from Reiners and others $(2002,2003)$ span a $100-\mathrm{km}$ N-S distance in the Cascade Range, primarily in what we have defined as the North Cascades. Other data for the Cascade region exist (Reiners and other, 2002, 2003), however, we have selected here only the data that appear free of thermal effects resulting from magmatic activity. In the area covered by these data, long-term average exhumation rates range from 0.02 to $0.1 \mathrm{~km} \mathrm{My}^{-1}$ east of the drainage divide, and do not have any N-S trend (fig. 12). West of the drainage divide, however, exhumation rates range from 0.05 to 0.11 $\mathrm{km} \mathrm{My}^{-1}$ in the north and generally increase to a maximum of $0.33 \mathrm{~km} \mathrm{My}^{-1}$ to the south (fig. 12). 


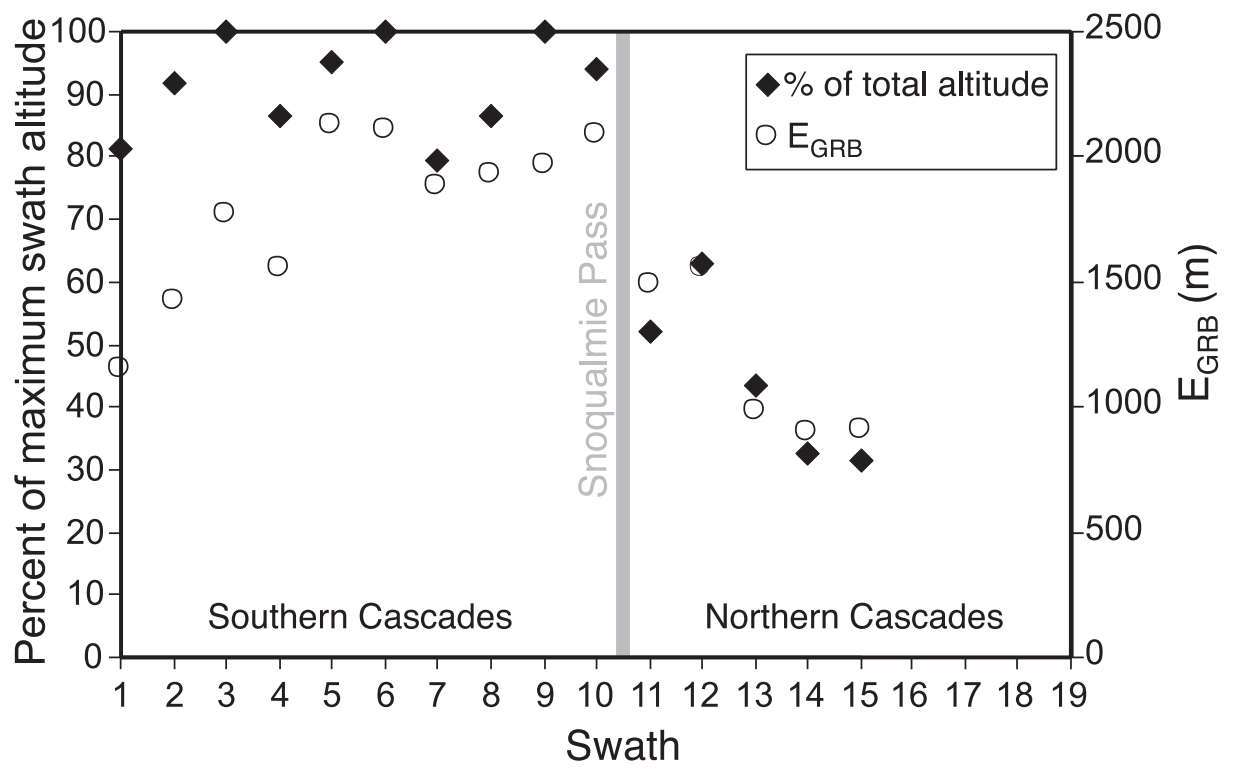

Fig. 10. Open circles show the elevation of the highest exposure of GRB ( $\left.\mathrm{E}_{\mathrm{GRB}}\right)$ in each swath, black diamonds show $\mathrm{E}_{\mathrm{GRB}}$ as a percentage of the maximum elevation within each swath, excluding Quaternary volcanoes. Note there are no GRB exposures in swaths 16 to 19.

DISCUSSION

The topographic, geologic, and thermochronometric evidence collectively supports the polygenetic model for topographic development of the Cascade Range in

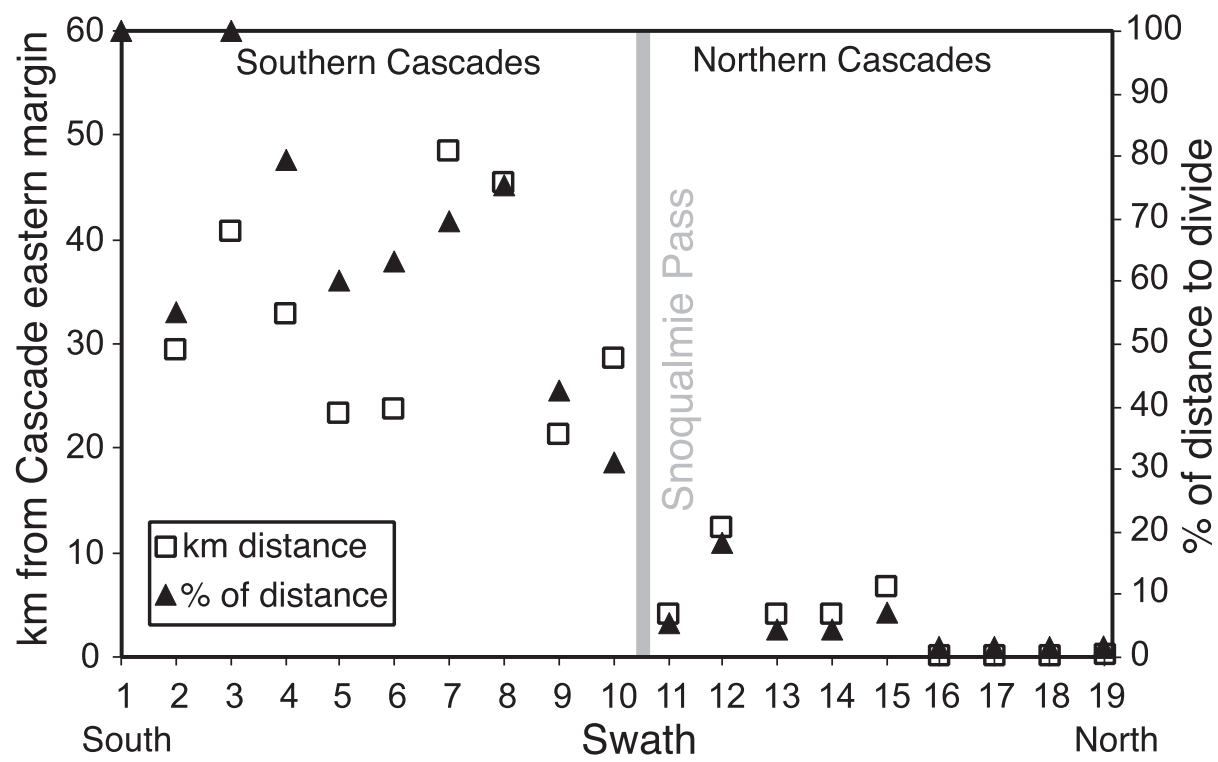

Fig. 11. Absolute and relative position of the western GRB margin. Open squares show the distance between the western GRB limit and the eastern edge of the range. Black triangles indicate the location of the western GRB limit relative to the width of the range between the drainage divide and the eastern limit $(100 \%$ means the GRB reaches the divide, $0 \%$ means no GRB is located within the Cascade physiographic province). 


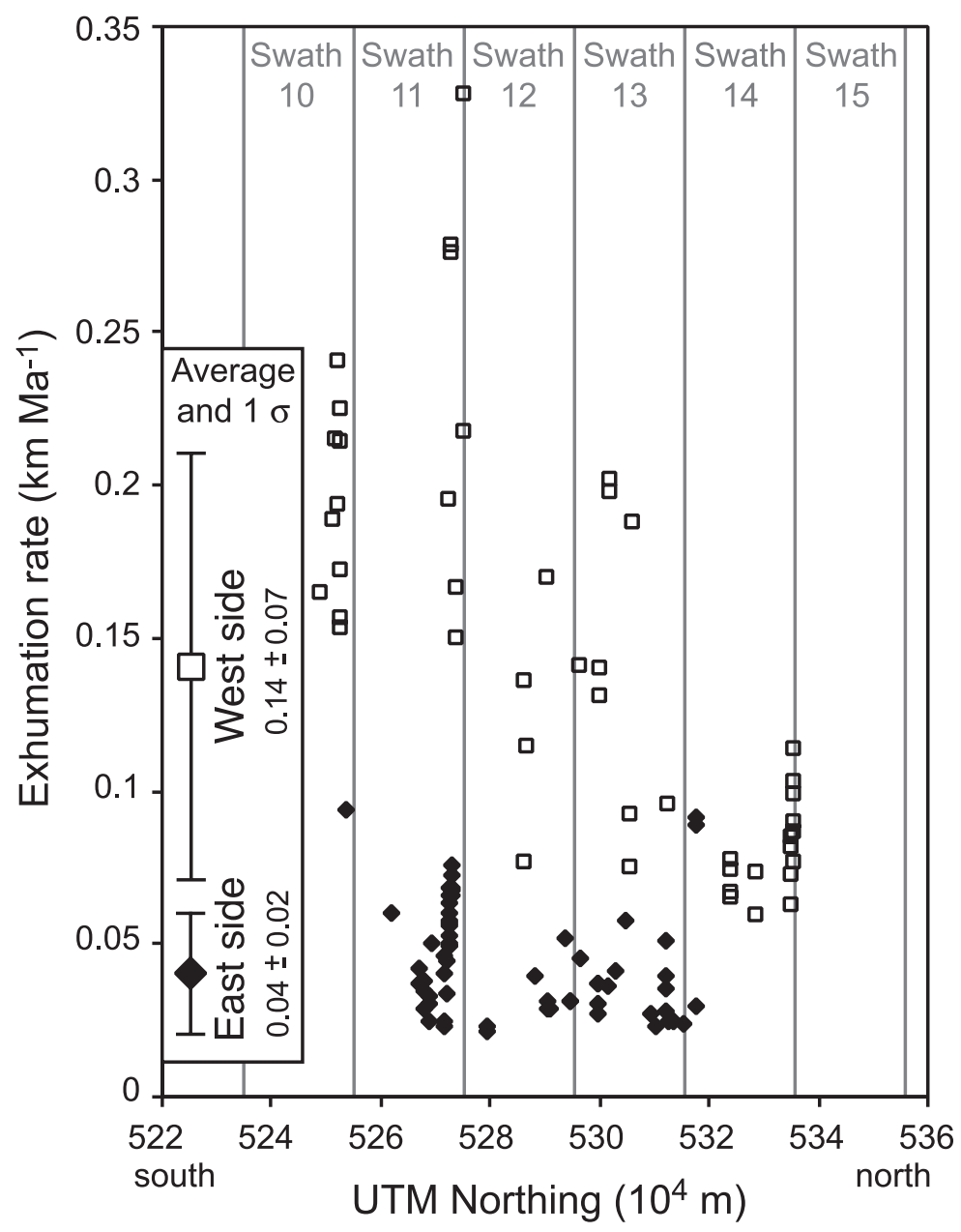

Fig. 12. North-south trends in long-term average exhumation rate, determined from apatite U-Th/He thermochonometric ages from exposed plutons and assuming constant exhumation (Reiners and others, 2002, 2003, unpublished data). Solid diamonds are from samples located east of the drainage divide, squares are from samples located west of the divide. Swaths are shown in gray; note that the southernmost samples are located in Swath 10. There is no trend in exhumation rate with respect to latitude on the east side of the range, while exhumation rates generally decrease towards the north on the west side of the range.

Washington. Indeed, the polygenetic model also resolves evidence previously considered to provide contradictory support for either low- or high-relief paleotopography.

\section{Grande Ronde Basalt and Topography}

The topographic and spatial relationships of the GRB to Cascade topography confirm there was low relief in the area now forming the southeastern flank of the Cascades during the middle Miocene. Given that basalt does not flow uphill and assuming that the upper surfaces of the GRB flows initially were roughly horizontal, the areas where basalt is preserved had low relief during the middle Miocene. Because this low relief footprint covers the entire eastern flank of the southern Cascades, any basalt-blocking relief in the Miocene must have been 20 to $50 \mathrm{~km}$ west of the current 
eastern edge of the Cascades 17 My ago. As suggested by Mackin and Cary (1965), low relief topography could have extended beyond the footprint indicated by the basalt in southern Washington, and connected with the other CRB flows found closer to the Washington coast. In the North Cascades, the footprint of definitively low Miocene relief is limited to within 4 to $12 \mathrm{~km}$ of the eastern edge of the modern range and is consistent with the North Cascades standing above the encroaching basalt flows.

Not only do modern GRB exposures exist closer to the drainage divide in the southern Cascades than in the North Cascades, the basalt outcrops also reach altitudes $\sim 1000 \mathrm{~m}$ higher in the south than in the north and are even exposed at the crest of the range in the southern region. This N-S difference in basalt altitude could be explained by several hypotheses. If the Cascades existed prior to the emplacement of the CRB and the modern basalt margin is depositional across both the North and southern Cascades, the basalt could be higher in the south because it either flowed closer to the axis of post-Miocene uplift in the south than it did in the north, or the amount of rock uplift was greater in the south than in the north. Alternatively, if the basalt margin on the east flank of the Cascades is erosional, the difference in basalt altitude between the north and south could be due to greater erosional stripping of the basalt in the north. Porter (1976) suggested that CRB may have once covered more of the eastern North Cascades, preserving a series of low-relief, tilted erosion surfaces that appear to follow the trend of basalt flow surfaces. This hypothesis raises the same question as above; if pre-CRB topography had low relief and CRB once covered the entire range, why would the basalt be missing from the North Cascades but be preserved in the southern Cascades? This question is especially pertinent on the east side of the range, where precipitation and long-term exhumation rates are quite low $\left(<0.1 \mathrm{~km} \mathrm{My}^{-1}\right.$, Reiners and others, 2002, 2003).

One possible explanation is that glacial erosion preferentially removed basalt from the north and not the south. For example, only the Cascades in far northern Washington were covered by ice of the Cordilleran Ice Sheet (Booth and others, 2004) (fig. 13A). However, the Cascade Range in central and southern Washington was also extensively covered with alpine valley glaciers during the last several Quaternary glaciations (S.C. Porter, personal communication, 2002) (fig. 13A). A comparison between the Quaternary maximum glacial extent and the modern extent of the CRB shows that the ice extended eastward to (and locally overlaps) what is now the edge of the basalt in the southern Cascades (fig. 13B). The overlap between the glacial and CRB margins in the southern Cascades is consistent with glaciers having removed CRB from the landscape, at least along main valleys. However, north of Snoqualmie Pass, the ice extent at the glacial maximum does not abut or overlap the modern CRB limit (fig. 13B). We thus cannot invoke preferential glacial erosion to explain the lack of CRB on the east flank of the North Cascades.

The N-S trends in long-term average exhumation rate also support the interpretation that the North Cascades had significant relief prior to the emplacement of the CRB, and that the two regions of the Cascades have not experienced greatly different exhumation histories since the middle Miocene. Although we lack exhumation rate data from the far northern and far southern portions of our study area, available data from the central and northern part of the study area suggest that exhumation rates either do not change (east side) or increase (west side) to the south. If the entire range had low relief at the time of CRB emplacement, and the North Cascades have subsequently been uplifted and exhumed to a much greater extent than the southern Cascades, we should expect either an abundance of reset AHe ages in the north or higher post-Miocene exhumation rates in the north than the south. However, figure 12 shows the opposite, consistent with our polygenetic model. 

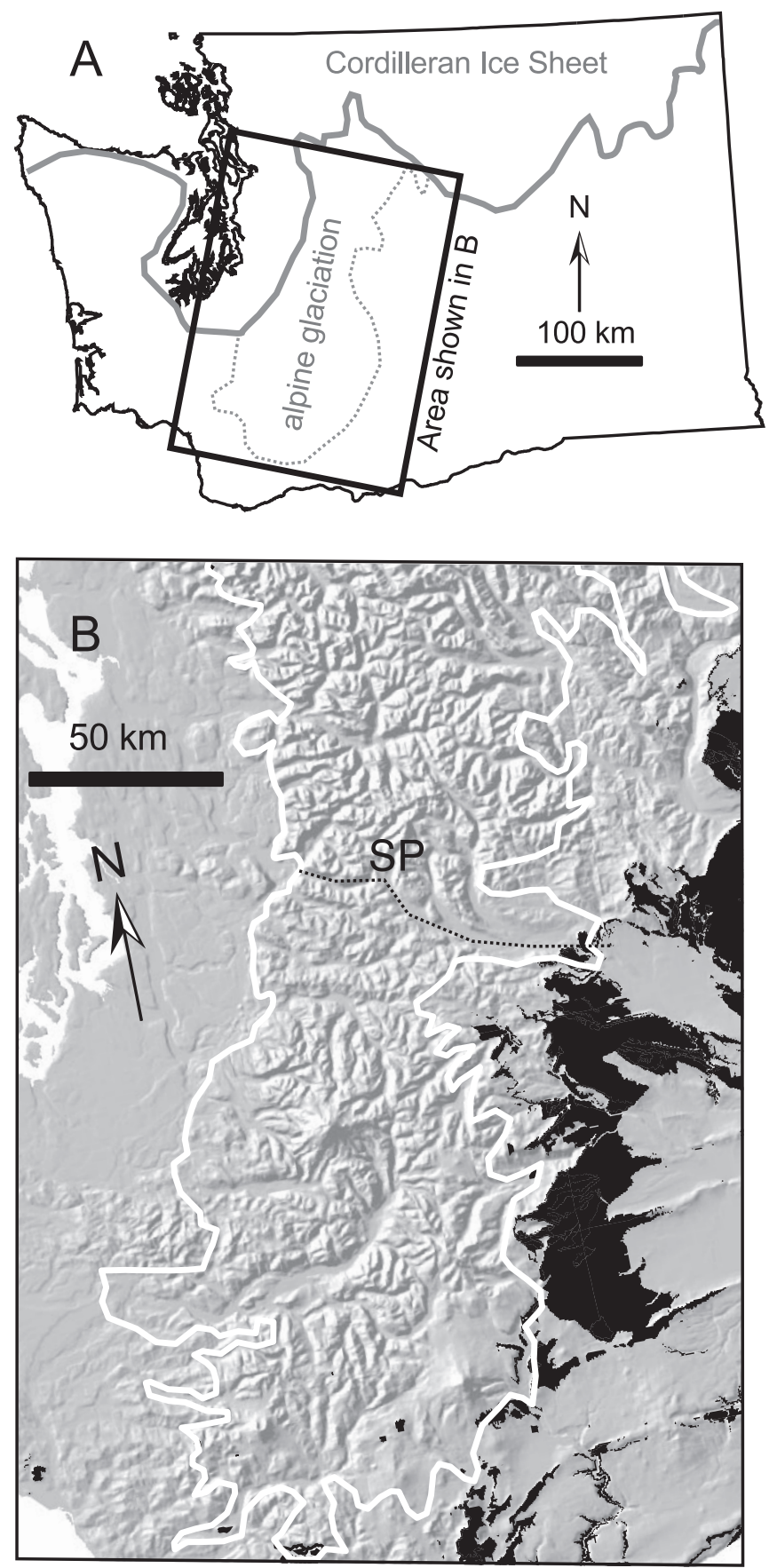

Fig. 13. (A) Approximate Quaternary maximum glacial limits in Washington. Solid gray line indicates the southern limit of the Cordilleran Ice Sheet (Booth and others, 2004); dotted gray line indicates the approximate limit of Cascade alpine glaciation (S. C. Porter, personal communication, 2002). (B) Detailed view of Quaternary maximum glacial extent in the Cascade Range. The heavy white line shows the downstream limit of alpine glaciers, excluding nunataks and other unglaciated areas that were exposed in the core of the range (S.C. Porter, personal communication, 2002). Grande Ronde Basalt exposures are shown as solid black. Snoqualmie Pass is labeled (SP) and the boundary between the northern and southern Cascade regions is marked with a dashed line. The basalt and glacial margins locally overlap in the south but do not in the north. 


\section{Geologic Context}

A polygenetic origin of Cascades topography is not only consistent with the geographic and thermochronologic data and analyses, but such an interpretation of the Cascade Range topographic evolution is also consistent with the geologic history and geophysical setting of the range. In the following section, we discuss the geologic and tectonic history of the Cascades, and how these relate to our physiographic model.

The history of mountain building in Washington State long precedes the Miocene. The main backbone of the northern Washington Cascades accreted during the middle Cretaceous (Saleeby and others, 1992). Deformation resulting from the docking and suturing of terranes on the west coast of North America at this time caused up to $500 \mathrm{~km}$ of shortening, resulting in extensive crustal thickening and metamorphism. The current exposure of highly metamorphosed formations in the northern Washington Cascades today attests to tens of kilometers of structural and erosional exhumation since that time (Haugerud and others, 1991; McGroder, 1991; Valley and others, 2003). This evidence of crustal thickening and exhumation suggests that the middle Cretaceous was a time of mountain building in northern Washington. Although the pre-Paleogene basement of the southern Washington Cascades is almost completely covered by Cenozoic sedimentary and volcanic rocks, gravity data and a southern Cascade exposure of pre-Paleogene melange and metamorphic rocks correlates with those exposed in the northern Cascades and suggests that a relatively continuous accreted crystalline core probably underlies the entire Cascades and plunges under the Cenozoic cover in southern Washington (Miller, 1989; Saltus, 1993).

During the early Cenozoic, collision and subduction appear to have slowed while sedimentation and extension of fault-bounded basins began (Johnson, 1984; Christensen and others, 1992). During this time, widespread and km-thick fluvial and shallow marine sediments were deposited along the western edge and across the middle of the Cascade Range in Washington (fig. 14A). These sediments have been interpreted to have been "deposited by meandering rivers that flowed westward across a broad coastal plain that existed prior to the uplift of the Cascade Range," indicating a large region of low relief at that time (Johnson, 1984). However, the great thickness (some sections are $6 \mathrm{~km}$ thick), volume, and grain size of these Eocene sediments attest not only to the rapid subsidence of the basins, but to the presence of a nearby, rapidly uplifting source region (Johnson, 1984; Christiansen and others, 1992). The source regions of these sediments have been thought to be sourced in distant regions to the north and east of the Cascades (Mathews, 1981; R. Evarts, personal communication, 2005), but may also include rocks from the North Cascades, including the Chiwaukum Schist and Mt. Stuart batholith (Vance, 2002). The presence of North Cascade lithologies in Eocene coastal plain sediments indicates that the crystalline core of the North Cascades was exposed and had a steep enough topographic gradient to shed sand- to gravel-sized sediment at that time. All of these early Eocene sedimentary deposits were subsequently folded and faulted (Foster, 1960; Gresens, 1980).

The next geomorphically significant phase in Cascade geology was the renewal of arc volcanism, fed by the renewed subduction of the Farallon/Juan de Fuca plate to the west $\sim 40$ My ago (Smith, 1993). In the North Cascades, this period of magmatic activity is evidenced by the development of numerous intrusive igneous bodies (Dragovich and others, 2002) (fig. 14B). It is thought that these batholiths and plutons are the crystallized magma chambers that once fed a chain of volcanoes of unknown extent and altitude. In the north, any extrusive rocks of these volcanoes have long since eroded away, potentially indicating that relief in the north was high enough to drive relatively rapid erosion of the volcanoes. Conversely, both extrusive and intrusive rocks 
are widely preserved in the southern Cascades of Washington (for example, Walsh and others, 1987). During or after this interval of volcanic activity, the southern Cascades subsided, deforming these volcanic rocks into a broad synform with an axis roughly parallel to the modern drainage divide of the range (Evarts and Swanson, 1994; Hammond, 1998). These volcanic deposits subsided so much that $100 \mathrm{~s}$ of $\mathrm{m}$ were preserved and were later intruded by slightly younger (Miocene) plutons (Power and others, 1981; Evarts and Swanson, 1994). The evidence of subsidence and lack of erosion of the volcanic rocks suggests low relief in southern Washington at this time.

By the middle Miocene, volcanic activity was still a dominant process throughout the range. Clasts of extrusive rocks associated with middle Miocene plutonism in the southern Cascades occur in sedimentary and volcaniclastic deposits that flank the Cascades (Smith and others, 1989). The Ellensburg Formation (16- to 7-My-old Ma, Smith and others, 1989) consists of fluvial and pyroclastic deposits of primarily volcanic and volcaniclastic origin preserved on the east side of the Cascades (fig. 14C). Most of the Ellensburg Formation is now found south of Snoqualmie pass, though small exposures exist as far north as Wenatchee. The contemporaneous Mashel Formation, which also consists primarily of fluvially transported volcanic sediment, is found on the west side of the range (Mullineaux and others, 1959; Walters and Kimmel, 1968). These coarse-grained deposits, much like the earlier Eocene sediments, must have formed on or adjacent to topography steep enough to generate and transport gravel-to-cobble sized clasts, for example, on the flanks of volcanoes. However, as Mackin and Cary (1965) suggested, middle- to late-Miocene volcanoes did not necessarily form a continuous upland in southern Washington. Any parts of the landscape high enough to block the flow of nearly planar sheets of fluid lava must have been located to the west of the modern basalt outcrops, and does not exclude the possibility that the basalt once covered more of the Cascade Range in southern Washington. Subsequent uplift and differential erosion on the wetter west side of the range could have removed any CRB that may have once covered the west flank of the southern Cascades.

The paleobotanical and isotopic evidence of rainshadow formation is also consistent with a polygenetic topographic history of the Cascades in Washington. The majority of fossil evidence for the transition from mesic to xeric ecosystems in eastern Washington comes from central and southern regions of the state (Chaney, 1938; Beck, 1945; Smiley, 1963; Leopold and Denton, 1987; Takeuchi and Larson, 2005) (fig. 14D). Chaney $(1938,1959)$ focused on eastern Oregon, studying only a few sites in southern Washington and no sites north of Snoqualmie Pass. Smiley (1963) worked in the Ellensburg formation of south-central Washington. Although this formation is also found further north, Smiley (1963) did not study any sections north of Wenatchee. Leopold and Denton (1987) and Takeuchi and Larson (2005) also had sites located only in southern Washington (fig. 14D). Thus, while the evidence appears conclusive that a significant climate change occurred in south- and central-eastern Washington from $\sim 16$ to $8 \mathrm{My}$ ago, few data are available to document a similar phenomenon in northern Washington. Therefore, it is possible that there was already significant relief in northern Washington $16 \mathrm{My}$ ago as the southern Washington Cascades rose and created a rainshadow.

\section{Tectonic Context}

Although the tectonic explanation for the post-Miocene surface and rock uplift of the Cascades in Washington remains a matter of debate, this uplift is likely the result of a combination of regional and local forcing. Regionally, there appears to have been a pulse of rapid exhumation, and therefore inferred rapid rock uplift, along much of the northwest coast of North America between 12 and 10 My ago (Wahrhaftig and others, 1969; Parrish, 1983; Brandon and others, 1998; Reiners and others, 2002). This regional-scale pulse in inferred rock uplift may be related to a change in relative plate 


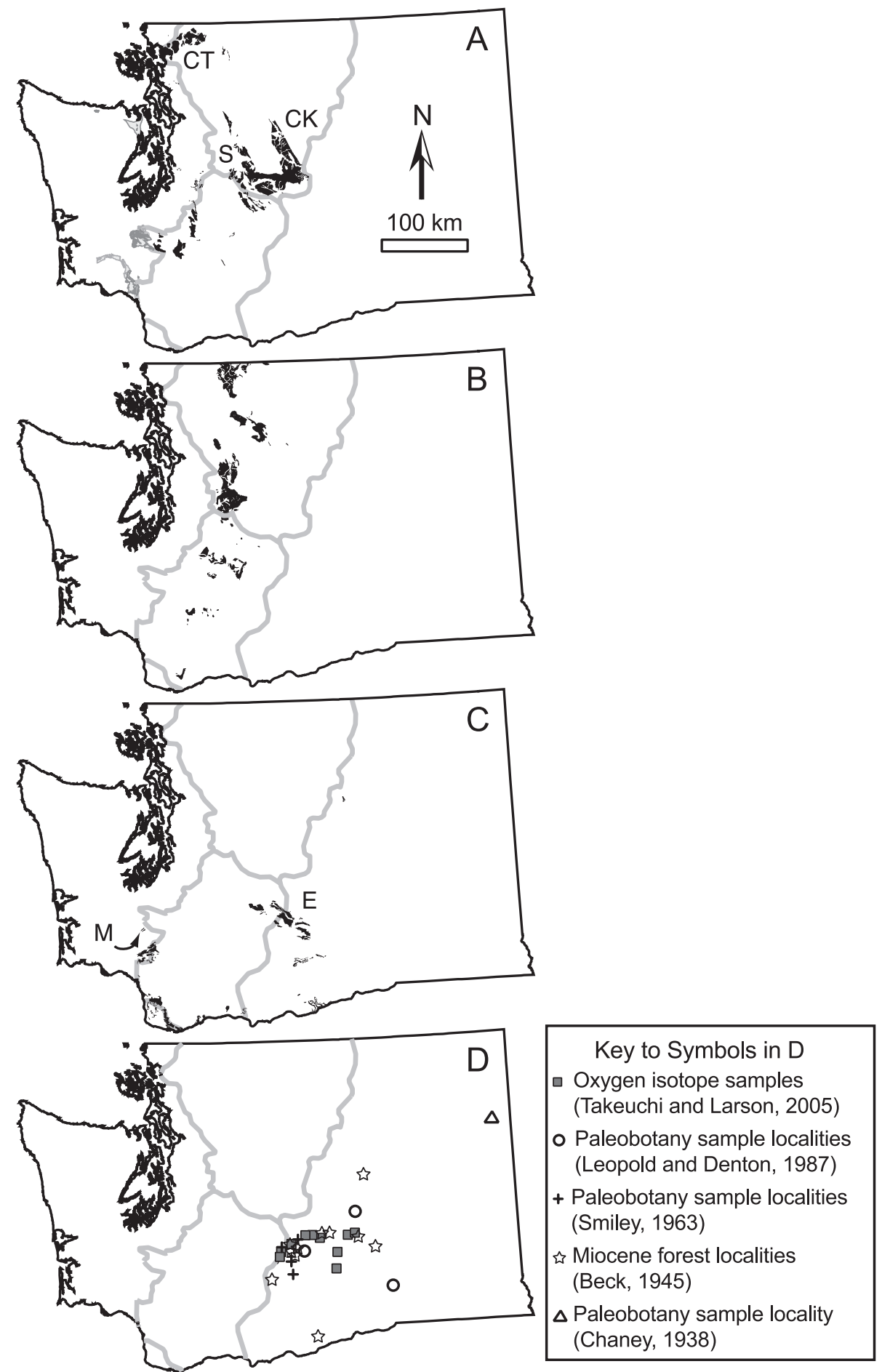

Fig. 14. (A) Major Eocene sedimentary units. Continental (fluvial) deposits including sandstones and conglomerates of the Chuckanut (CT), Swauk (S) and Chumstick (CK) Formations are shown in black, fine-grained marine deposits are shown in gray. (B) Plutons resulting from Cascade arc magmatism, Eocene 
motions or delamination of the lower crust along the North American coast (Reiners and others, 2002). The tectonic evidence that the southern Cascade Range is also experiencing localized north-south compression and shortening includes paleomagnetic evidence of post-Miocene rotation, GPS measurements of modern crustal movements, and historic seismicity, each of which is discussed below.

Determinations of crustal motions from paleomagnetic and GPS data suggest that southern Washington is being rotated and compressed against the crystalline foundation of the North Cascades and Coast Range of British Columbia. Paleomagnetic data show that there has been significant $\left(10-35^{\circ}\right)$ clockwise rotation in $<30$-My-old rocks in the southern Cascades relative to a fixed North American datum (Bates and others, 1981; Wells, 1990; England and Wells, 1991; Hagstrum and others, 1999). Rotation and northeastern movement of the Cascade Range in southern Washington is also evident in GPS velocities (for example, Wells and others, 1998; Svarc and others, 2002; Mazzotti and others, 2003) and north-south compression is evident in recent seismicity (Stanley and others, 1996). This rotation in southern Washington is probably due to a combination of dextral shear resulting from the subduction angle at the plate margin and effects of Basin and Range extension (fig. 1B) (Wells, 1990; Hagstrum and others, 1999). In contrast, rocks in the North Cascades have not experienced rotation since the Miocene, are not currently moving to the northeast relative to a fixed North America, and are relatively seismically inactive (for example, Wells, 1990; Stanley and others, 1996; Wells and others, 1998; Svarc and others, 2002). Although we have not modeled the specific effects of tectonic differences on the uplift of the Cascades, the observed differences in past and present rotation and seismicity are consistent with the hypothesis that the southern Washington Cascades experienced additional regional surface uplift superimposed upon the larger-scale (and still enigmatic) pulse of exhumation and inferred rock uplift that appears to have affected the entire northwestern Pacific coast during the Miocene. This north-south compression of the southern Cascades against the North Cascades likely explains why the highest CRBs are found right at the transition between the two regions, as that is where the gradient in crustal velocity is the highest.

\section{Modern Topography}

Despite differences in both geologic and tectonic history between the northern and southern Cascades, why are the differences in the maximum and mean altitudes between the regions subtle and gradational, particularly on the western flank? First, greater uplift in the originally lower southern Cascades due to additional north-south compression may have obscured original differences in altitude between the two

\footnotetext{
to Miocene age. (C) Mid-Miocene continental sediments, including the Ellensburg Formation (E) and the Mashel Formation (M). (D) Location of paleobotany and oxygen isotope samples from Washington used to infer the development of an orographic rainshadow during the Miocene. Samples for oxygen isotope analysis (Takeuchi and Larson, 2005) shown as gray squares. These samples range in age from $<1$ My to 15.6 $\mathrm{My}$, and show a progressive lightening of $\delta^{18} \mathrm{O}$ values through that time. Field locations of flora from the Ellensburg Formation from Smiley (1963) are shown as crosses. Locations of other well-known Miocene floras indicating a more humid ecosystem than today are shown as open circles (Leopold and Denton, 1987). Locations of Miocene forests from Beck (1945) are marked with stars; however, these sites only show a single snapshot of climate, not a temporal evolution like the other data sets. Finally, the Washington field site of Chaney (1938) is shown as an open triangle. Generalized contacts are derived from the digitized version of a 1:500,000-scale geologic map of Washington State (Hunting and others, 1961); geologic formation identifications are from the 60-minute, 1:100,000-scale geologic maps of Washington State (Tabor and Cady, 1978; Tabor and others, 1982; Frizzell and others, 1984; Walsh, 1986b; Korosec, 1987a, 1987b; Logan, 1987; Phillips, 1987a, 1987b; Phillips and Walsh, 1987; Schasse, 1987a, 1987b; Tabor and others, 1987; Walsh, 1987a, 1987b; Tabor and others, 1988; Whetten and others, 1988; Bunning, 1990; Gulick and Korosec, 1990a; Soffel and McGroder, 1990; Yount and Gower, 1991; Tabor and others, 1993; Schuster, 1994a, 1994b, 1994c; Tabor and others, 1994; Dragovich and Norman, 1995; Tabor and others, 2003).
} 
regions. In addition, we suggest that erosional processes masked the topographic differences between the northern and southern Washington Cascades since the uplift of the Cascade Range antiform. There are two distinct climatic gradients in the Cascades that affect erosion patterns: the strong $\mathrm{W}$-E variation in precipitation resulting from the rainshadow effect, and the strong altitudinal control on glacial erosion processes (Mitchell and Montgomery, 2006). Once the range, northern and southern, became high enough to interfere with weather systems bringing in moisture from the west, increased precipitation on the west side increased fluvial, hillslope, and glacial erosion, while precipitation and erosion rates decreased on the east side (Reiners and others, 2003). Also, once the climate was cold enough and the range high enough to intersect the glacial equilibrium line altitude, glacial erosion increased erosion rates and limited how high the peaks could rise on the west flank of the range regardless of uplift rate. The spatial correspondence of the edge of alpine glaciation and the extent of the CRB suggests that glacial erosion also contributed to the removal of CRB from the southern part of the range (fig. 13). Both of these climatic influences on post-uplift erosion are largely independent of rock type and of latitude, and thus this erosion may have erased any prior differences in peak altitude between the northern and southern Cascade Range in Washington, most noticeably on the western flank.

The increase in average slope and relief towards the north could be due to differences in the average rock hardness and resistance to erosion in the two regions. Resistant, crystalline rocks that form most of the northern part of the range may be capable of maintaining steeper slopes and thus higher relief than the less-resistant, more highly jointed volcanic and sedimentary rocks in the south (for example, Schmidt and Montgomery, 1995). Even with steeper slopes and more relief, the harder rocks exposed in the northern Cascades appear to be eroding at a similar or slower average rate as those in the south, particularly on the east flank of the range (fig. 12).

SUMMARY

Because previous investigations of Cascades physiography focused on particular regions, outcrops, or features, prior interpretations regarding topographic development appear biased according to the location and type of evidence available. By integrating our analyses with the geologic evidence previously used to infer local paleotopography into a regional context, we resolve apparent contradictions in prior ideas and observations regarding the topographic evolution of the range. Specifically, our reanalysis of prior studies in light of new topographic analyses support a polygenetic model for development of the topography of the modern Cascade Range. We conclude that the North Cascades had enough relief during the Miocene to block CRB flows. During this same time, the southern Cascades probably had low to modest relief, punctuated by isolated volcanic centers. At least $\sim 1000 \mathrm{~m}$ of differential rock uplift subsequently occurred, as evidenced by the deformation of the CRB on the eastern flank of the range. The polygenetic model provides a reasonable singular underlying explanation for many of the observed phenomena, including: 1) the spatial distribution and vertical deformation of the CRB relative to the topography of the Cascade Range, 2) observed climate change in eastern Washington resulting from the raising of an orographic barrier, and 3) the spatial relationship between CRB outcrops and the extent of glaciation. This polygenetic model is also consistent with the differences in geology and tectonics between the two regions. Subsequent topographic modification of the range due to orographic effects and glacial erosion masked the differences in geology and topographic history, resulting in a single physiographic entity with a complex, polygenetic origin. 
ACKNOWLEDGMENTS

We thank Harvey Greenberg for GIS assistance, Darrel Cowan, Russell Evarts, Eric Cheney, and Ralph Haugerud for enlightening discussions regarding the physiography, geology, and tectonics of Washington State, and Stephen C. Porter and the late Richard J. Stewart for reviews of draft manuscripts. We also thank Peter Reiners for sharing unpublished apatite (U-Th)/He data. This manuscript was greatly improved by thoughtful and thorough reviews from Peter Reiners, Andrew Meigs, and Glenn Thackray. This research was supported by the National Science Foundation (NSF EAR-0087413 and a Graduate Research Fellowship) and the Department of Earth and Space Sciences at the University of Washington.

\section{REFERENCES}

Anderson, J. L., and Vogt, B. F., 1987, Intracanyon flows of the Columbia River Basalt group in the southwest part of the Columbia Plateau and adjacent Cascade Range, Oregon and Washington, in Schuster, J. E., editor, Selected papers on the geology of Washington: Bulletin of the Washington Department of Natural Resources, Division of Geology and Earth Resources, v. 77, p. 249-267.

Bates, R. G., Beck, M. E., Jr., and Burmester, R. F., 1981, Tectonic rotations in the Cascade Range of southern Washington: Geology, v. 9, p. 184-189.

Beck, G. F., 1945, Ancient forest trees of the sagebrush area in central Washington: Journal of Forestry, v. 43, p. $334-338$.

Beeson, M. H., and Tolan, T. L., 1989, The Columbia River Basalt Group in the Cascade Range-a middle Miocene reference datum for structural analysis, in Muffler, L. J. P., Weaver, C. S., and Blackwell, D. D. editors, Proceedings of workshop XLIV-Geological, geophysical and tectonic setting of the Cascade Range: United States Geological Survey Open File Report 89-178, p. 257-290.

Booth, D. B., Troost, K. G., Clague, J. J., and Waitt, R. B., 2004, The Cordilleran Ice Sheet, in Gillespie, A. R., Porter, S. C., and Atwater, B. F., editors, The Quaternary Period in the United States: Developments in Quaternary Science, v. 1, p. 17-43.

Brandon, M. T., Roden-Tice, M. K., and Garver, J. I., 1998, Late Cenozoic exhumation of the Cascadia accretionary wedge in the Olympic Mountains, Northwest Washington State: Geological Society of America Bulletin, v. 110, p. 985-1009.

Bunning, B. B., 1990, Geologic map of the east half of the Twisp 1:100,000 quadrangle, Washington: Washington Division of Geology and Earth Resources Open File Report 90-9, scale 1:100,000.

Campbell, N. P., 1988, Structural geology along the northwestern Columbia River basalt margin, Washington: Washington Division of Geology and Earth Resources Open File Report 88-5, 108 p.

Chamberlain, C. P., and Poage, M. A., 2000, Reconstructing the paleotopography of mountain belts from the isotopic composition of authigenic minerals: Geology, v. 28, p. 115-118.

Chaney, R. W., 1938, Paleoecological interpretations of Cenozoic plants in western North America: Botanical Review, v. 4, p. 371-396.

- 1959, Miocene floras of the Columbia Plateau-Part 1, Composition and interpretation: Carnegie Institution of Washington Publication 617, p. 1-34.

Cheney, E. S., 1997, What is the age and extent of the Cascade magmatic arc?: Washington Geology, v. 25, p. 28-32.

Christiansen, R. L., Yeats, R. S., Graham, S. A., Niem, W. A., Niem, A. R., and Snavely, P. D., Jr., 1992 Post-Laramide geology of the U.S. Cordilleran region, in Burchfiel, B. C., Lipman, P. W., and Zoback, M. L., editors, The Cordilleran Orogen; conterminous U.S.: Geological Society of America, The Geology of North America, v. G-3, p. 261-406.

Dragovich, J. D., and Norman, D. K., 1995, Geologic map of the west half of the Twisp 1:100,000 quadrangle, Washington: Washington Division of Geology and Earth Resources Open File Report 95-3, scale $1: 100,000$

Dragovich, J. D., Logan, R. L., Schasse, H. W., Walsh, T. J., Lingley, W. S., Norman, D. K., Gerstel, W. J., Lapen, T. J., Schuster, J. E., and Meyers, K. D., 2002, Geologic map of Washington; northwest quadrant: Washington Division of Geology and Earth Resources Geologic Map GM-50, scale 1:250,000

England, P. C., and Molnar, P., 1990, Surface uplift, uplift of rocks, and exhumation of rocks: Geology, v. 18 , n. 12, p. 1173-1177.

England, P. C., and Wells, R. E., 1991, Neogene rotations and quasicontinuous deformation of the Pacific Northwest continental margin: Geology, v. 19, p. 978-981.

Evarts, R. C., and Swanson, D. A., 1994, Geologic transect across the Tertiary Cascade Range, southern Washington, in Swanson, D. A., and Haugerud, R. A., editors, Geologic field trips in the Pacific Northwest: University of Washington, Department of Geological Sciences, v. 2, p. 2H 1 - 2H 31.

Farley, K. A., 2002, (U-Th)/He dating: Techniques, calibrations, and applications, in Porcelli, P. D., Ballentine, C. J., and Wieler, R., editors, Noble Gases in Geochemistry and Cosmochemistry: Reviews in Mineralogy and Geochemistry, v. 47, p. 819-844.

Foster, R. J., 1960, Tertiary geology of a portion of the central Cascade Mountains, Washington: Bulletin of the Geological Society of America, v. 71, p. 99-126.

Frizzell, V. A., Jr., Tabor, R. W., Booth, D. B., Ort, K. M., and Waitt, R. B., 1984, Preliminary geologic map of the Snoqualmie Pass 1:100,000 quadrangle, Washington: U.S. Geological Survey Open-File Report 84-693, scale1:100,000. 
Gresens, R. L., 1980, Deformation of the Wenatchee Formation and its bearing on the tectonic history of the Chiwaukum Graben, Washington, during Cenozoic time: Geological Society of America Bulletin, v. 91, n. 1, part 1, p. 4-7, part 2, p. 115-155.

Gulick, C. W., and Korosec, M. A., 1990a, Geologic map of the Banks Lake 1:100,000 quadrangle, Washington: Washington Division of Geology and Earth Resources Open File Report 90-6, scale $1: 100,000$.

_ 1990b, Geologic map of the Omak 1:100,000 quadrangle, Washington: Washington Division of Geology and Earth Resources Open File Report 90-12, scale 1:100,000.

Hagstrum, J. T., Swanson, D. A., and Evarts, R. C., 1999, Paleomagnetism of an east-west transect across the Cascade arc in southern Washington-Implications for regional tectonism: Journal of Geophysical Research, v. 104, n. B6, p. 12,853-12,863.

Hammond, P. E., 1988, The Cascade paleosurface: Geological Society of America Abstracts with Programs, v. 20, n. 7 , p. A284.

1998, Tertiary andesitic lava-flow complexes (stratovolcanoes) in the southern Cascade Range of Washington-observations on tectonic processes within the Cascade arc: Washington Geology, v. 26, p. $20-30$.

Hammond, P. E., Brunstad, K. A., Hooper, P. R., and Cole, S. F., 1992, Isolated occurrences of Columbia River basalt flows at Steamboat Mountain, southern Washington Cascade Range-Indication of yet greater westward extent of these flood-basalt flows: Oregon Academy of Sciences, ProceedingsVolume XXVIII: Oregon Academy of Science, p. 38.

Haugerud, R. A., 2004, Cascadia-Physiography: USGS Miscellaneous Investigations Map I-2689.

Haugerud, R. A., van der Heyden, P., Tabor, R. W., Stacey, J. S., and Zartman, R. E., 1991, Late Cretaceous and early Tertiary plutonism and deformation in the Skagit Gneiss Complex, North Cascade Range, Washington and British Columbia: Geological Society of America Bulletin, v. 103, p. 1297-1307.

Hunting, M. T., Bennett, W. A., Livingston, V. E., Jr., and Moen, W. S., 1961, Geologic Map of Washington: Washington Department of Conservation, Division of Mines and Geology, scale 1:500,000.

Johnson, S. Y., 1984, Stratigraphy, age, and paleogeography of the Eocene Chuckanut Formation, Northwest Washington: Canadian Journal of Earth Sciences, v. 21, p. 92-106.

Korosec, M. A., 1987a, Geologic map of the Hood River quadrangle, Washington and Oregon: Washington Division of Geology and Earth Resources Open File Report 87-6, scale 1:100,000.

— 1987b, Geologic map of the Mount Adams quadrangle, Washington: Washington Division of Geology and Earth Resources Open File Report 87-5, scale 1:100,000.

Leopold, E. B., and Denton, M. F., 1987, Comparative age of grassland and steppe east and west of the northern Rocky Mountains: Annals of the Missouri Botanical Garden, v. 74, p. 841-867.

Logan, R. L., 1987, Geologic map of the Chehalis River and Westport quadrangles, Washington: Washington Division of Geology and Earth Resources Open File Report 87-8, scale 1:100,000.

Mackin, J. H., and Cary, A. S., 1965, Origin of Cascade landscapes: Washington Division of Mines and Geology Information Circular 41, $35 \mathrm{p}$.

Mathews, W. H., 1981, Early Cenozoic resetting of potassium-argon dates and geothermal history of North Okanagan area: British Columbia. Canadian Journal of Earth Sciences, v. 18, p. 1310-1319.

Mazzotti, S., Dragert, H., Henton, J., Schmidt, M., Hyndman, R., James, T., Lu, Y., and Craymer, M., 2003, Current tectonics of northern Cascadia from a decade of GPS measurements: Journal of Geophysical Research, v. 108, n. B12, doi: 10.1029/2003JB002653.

McDaniel, P. A., Othberg, K. L., and Breckenridge, R. M., 1998, Paleogeomorphic evolution of the Columbia River basalt embayments, western margin of the northern Rocky Mountains-Part II, Miocene paleosols: Geological Society of America Abstracts with Programs, v. 30, n. 6, p. 15.

McGroder, M. F., 1991, Reconciliation of two-sided thrusting, burial metamorphism, and diachronous uplift in the Cascades of Washington and British Columbia: Geological Society of America Bulletin, v. 103, p. 189-209.

Miller, R. B., 1989, The Mesozoic Rimrock Lake inlier, southern Washington Cascades: Implications for the basement to the Columbia Embayment: Geological Society of America Bulletin, v. 101, p. 1289-1305.

Mitchell, S. G., and Montgomery, D. R., 2006, Influence of a glacial buzzsaw on the height and morphology of the Washington Cascade Range, USA: Quaternary Research, v. 65, p. 96-107.

Montgomery, D. R., and Greenberg, H. M., 2000, Local relief and the height of Mt. Olympus: Earth Surface Processes and Landforms, v. 25, p. 385-396.

Mullineaux, D. R., Gard, L. M., Jr., and Crandell, D. R., 1959, Continental sediments of Miocene age in Puget Sound lowland, Washington: American Association of Petroleum Geologists Bulletin, v. 43, n. 3, pt. 1, p. $688-696$.

Parrish, R. R., 1983, Cenozoic thermal evolution and tectonics of the coast mountains of British Columbia 1. Fission track dating, apparent uplift rates, and patterns of uplift: Tectonics, v. 2, p. 601-631.

Phillips, W. M., 1987a, Geologic map of the Mount St. Helens quadrangle, Washington and Oregon: Washington Division of Geology and Earth Resources Open File Report 87-4, scale 1:100,000.

_ 1987b, Geologic map of the Vancouver quadrangle, Washington [and Oregon]: Washington Division of Geology and Earth Resources Open File Report 87-10, scale 1:100,000.

Phillips, W. M., and Walsh, T. J., 1987, Geologic map of the northwest part of the Goldendale quadrangle, Washington: Washington Division of Geology and Earth Resources Open File Report 87-13, scale $1: 100,000$.

Porter, S. C., 1976, Geomorphic evidence of post-Miocene deformation of the eastern north Cascade Range: Geological Society of America Abstracts with Programs, v. 8, n. 3, p. 402-403.

Power, S. G., Field, C. W., Armstrong, R. L., and Harakal, J. E., 1981, K-Ar ages of plutonism and mineralization, western Cascades, Oregon and southern Washington: Isochron/West, n. 31, p. 27-29. 
Reidel, S. P., Tolan, T. L., Hooper, P. R., Beeson, M. H., Fecht, K. R., Bentley, R. D., and Anderson, J. L., 1989, The Grande Ronde Basalt, Columbia River Basalt Group; Stratigraphic descriptions and correlations in Washington, Oregon, and Idaho, in Reidel, S. P., and Hooper, P. R., editors, Volcanism and tectonism in the Columbia River flood-basalt province: Geological Society of America Special Paper 239, p. 21-53.

Reiners, P. W., Ehlers, T. A., Garver, J. I., Mitchell, S. G., Montgomery, D. R., Vance, J. A., and Nicolescu, S., 2002, Late Miocene exhumation and uplift of the Washington Cascade Range: Geology, v. 30, p. 767770 .

Reiners, P. W., Ehlers, T. A., Mitchell, S. G., and Montgomery, D. R., 2003, Coupled spatial variations in precipitation and long-term erosion rates across the Washington Cascades: Nature, v. 426, p. 645-647.

Russell, I. C., 1900, A preliminary paper on the geology of the Cascade mountains in northern Washington: United States Geological Survey Annual Report, 20th, Part 2, p. 83-210.

Saleeby, J. B., Busby, S. C., Oldow, J. S., Dunne, G. C., Wright, J. E., Cowan, D. S., Walker, N. W., and Allmendinger, R. W., 1992, Early Mesozoic tectonic evolution of the Western U.S. Cordillera, in Burchfiel, B. C., Lipman, P. W., and Zoback, M. L., editors, The Cordilleran Orogen; conterminous U.S.: Geological Society of America, The Geology of North America v. G-3, p. 107-168.

Saltus, R. W., 1993, Upper-crustal structure beneath the Columbia River Basalt Group, Washington-Gravity interpretation controlled by borehole and seismic studies: Geological Society of America Bulletin, v. 105 , p. $1247-1259$.

Schasse, H. W., 1987a, Geologic map of the Mount Rainier quadrangle, Washington: Washington Division of Geology and Earth Resources Open File Report 87-16, scale 1:100,000.

1987b, Geologic map of the Centralia quadrangle, Washington: Washington Division of Geology and Earth Resources Open File Report 87-11, scale 1:100,000.

Schmidt, K. M., and Montgomery, D. R., 1995, Limits to relief: Science, v. 270, n. 5236, p. 617-620.

Schmincke, H. U., ms, 1964, Petrology, paleocurrents, and stratigraphy of the Ellensburg Formation and interbedded Yakima Basalt flows, south-central Washington: Baltimore, Maryland, Johns Hopkins University, Ph.D. thesis, 426 p.

Schuster, J. E., 1992, Geologic map of Washington: Washington State Department of Natural Resources, Division of Geology and Earth Resources, scale 1:2,250,000.

_ 1994a, Geologic maps of the east half of the Washington portion of the Goldendale 1:100,000 quadrangle and the Washington portion of the Hermiston 1:100,000 quadrangle: Washington Division of Geology and Earth Resources Open File Report 94-9, scale 1:100,000.

_ 1994b, Geologic map of the east half of the Toppenish 1:100,000 quadrangle, Washington: Washington Division of Geology and Earth Resources Open File Report 94-10, scale 1:100,000.

_ 1994c, Geologic map of the east half of the Yakima 1:100,000 quadrangle, Washington: Washington Division of Geology and Earth Resources Open File Report 94-12, scale 1:100,000.

Searle, M. P., and Treloar, P. J., 1993, Himalayan Tectonics-an introduction, in Searle, M. P., and Treloar, P. J., editors, Himalayan Tectonics: Geological Society of America Special Publication, n. 74, p. 1-7.

Smiley, C. J., 1963, The Ellensburg flora of Washington: University of California Publications in Geological Sciences, v. 35, n. 3, p. 159-276.

Smith, G. A., 1988, Neogene synvolcanic and syntectonic sedimentation in central Washington: Geological Society of America Bulletin, v. 100, n. 9, p. 1479-1492.

Smith, G. A., Bjornstad, B. N., and Fecht, K. R., 1989, Neogene terrestrial sedimentation on and adjacent to the Columbia Plateau; Washington, Oregon and Idaho, in Reidel, S. P., and Hooper, P. R., editors, Volcanism and tectonism in the Columbia River flood-basalt province: Geological Society of America, Special Paper 239, p. 187-198.

Smith, G. O., 1903, Geology and physiography of central Washington: U.S. Geological Survey Professional Paper 19, p. 9-39.

Smith, J. G., 1993, Geologic map of upper Eocene to Holocene volcanic and related rocks in the Cascade Range, Washington: U.S. Geological Survey Miscellaneous Investigation, Map I-2005, scale 1:500,000.

Stanley, W. D., Johnson, S. Y., Qamar, A. I., Weaver, C. S., and Williams, J. M., 1996, Tectonics and seismicity of the southern Washington Cascade Range: Seismological Society of America Bulletin, v. 86, n. 1A, p. 1-18.

Stoffel, K. L., and McGroder, M. F., 1990, Geologic map of the Robinson Mtn. 1:100,000 quadrangle, Washington: Washington Division of Geology and Earth Resources Open File Report 90-5, scale $1: 100,000$.

Svarc, J. L., Savage, J. C., Prescott, W. H., and Murray, M. H., 2002, Strain accumulation and rotation in western Oregon and southwestern Washington: Journal of Geophysical Research, v. 107, n. B5, 2087, 10.1029/2001JB000625.

Swanson, D. A., 1997, Uplift of the southern Washington Cascades in the past 17 million years: Geological Society of America Abstracts with Programs, v. 29, n. 5, p. 68.

Summers, K. V., ms, 1976, Palagonite and pillow basalts of the Columbia River group: Pullman, Washington, Washington State University, M.Sc. thesis, 99 p.

Tabor, R. W., and Cady, W. M., 1978, Geologic map of the Olympic Peninsula, Washington: U.S. Geological Survey Miscellaneous Investigations Series Map I-994, scale 1:125,000.

Tabor, R. W., Waitt, R. B., Frizzell, V. A., Jr., Swanson, D. A., Byerly, G. R., and Bentley, R. D., 1982, Geologic map of the Wenatchee 1:100,000 quadrangle, central Washington: U.S. Geological Survey Miscellaneous Investigations Series Map I-1311, scale 1:100,000.

Tabor, R. W., Frizzell, V. A., Jr., Whetten, J. T., Waitt, R. B., Swanson, D. A., Byerly, G. R., Booth, D. B., Hetherington, M. J., and Zartman, R. E., 1987, Geologic map of the Chelan 30-minute by 60-minute quadrangle, Washington: U.S. Geological Survey Miscellaneous Investigations Series Map I-1661, scale $1: 100,000$ 
Tabor, R. W., Booth, D. B., Vance, J. A., Ford, A. B., and Ort, M. H., 1988, Preliminary geologic map of the Sauk River 30 by 60 minute quadrangle, Washington: U.S. Geological Survey Open-File Report 88-692, scale 1:100,000.

Tabor, R. W., Frizzell, V. A., Jr., Booth, D. B., Waitt, R. B., Whetten, J. T., and Zartman, R. E., 1993, Geologic map of the Skykomish River 30- by 60-minute quadrangle, Washington: U.S. Geological Survey Miscellaneous Investigations Series Map I-1963, scale 1:100,000.

Tabor, R. W., Haugerud, R. A., Booth, D. B., and Brown, E. H., 1994, Preliminary geologic map of the Mount Baker 30- by 60-minute quadrangle, Washington: U.S. Geological Survey Open-File Report 94-403, scale $1: 100,000$.

Tabor, R. W., Haugerud, R. A., Hildreth, W., and Brown, E. H., 2003, Geologic map of the Mount Baker 30by 60-minute quadrangle, Washington: U.S. Geological Survey Geologic Investigations Series I-2660, scale $1: 100,000$.

Takeuchi, A., and Larson, P. B., 2005, Oxygen isotope evidence for the last Cenozoic development of an orographic rain shadow in eastern Washington, USA: Geology, v. 33, p. 313-316.

Tolan, T. L., Reidel, S. P., Beeson, M. H., Anderson, J. L., Fecht, K. R., and Swanson, D. A., 1989, Revisions to the estimates of the areal extent and volume of the Columbia River Basalt Group, in Reidel, S. P., and Hooper, P. R., editors, Volcanism and tectonism in the Columbia River flood-basalt province: Geological Society of America Special Paper 239, p. 1-20.

Valley, P. M., Whitney, D. L., Paterson, S. R., Miller, R. B., and Alsleben, H., 2003, Metamorphism of the deepest exposed arc rocks in the Cretaceous to Paleogene Cascades belt, Washington: evidence for large-scale vertical motion in a continental arc: Journal of Metamorphic Geology, v. 21, p. 203-220.

Vance, J. A., 2002, Age and provenance of Eocene nonmarine sandstones in the central and Northwest Washington Cascades: fission track evidence from detrital zircons: Geological Society of America Abstracts with Programs, v. 34, n. 5.

Wahrhaftig, C., Wolfe, J. A., Leopold, E. B., and Lanphere, M. A., 1969, The coal-bearing group in the Nenana Coal Field, Alaska: U.S. Geological Survey Bulletin 1274, p. D1-D30.

Walsh, T. J., 1986a, Geologic map of the west half of the Toppenish quadrangle, Washington: Washington Division of Geology and Earth Resources Open File Report 86-3, scale 1:100,000.

- 1986b, Geologic map of the west half of the Yakima quadrangle, Washington: Washington Division of Geology and Earth Resources Open File Report 86-4, scale 1:100,000.

- 1987a, Geologic map of the south half of the Tacoma quadrangle, Washington: Washington Division of Geology and Earth Resources Open File Report 87-3, scale 1:100,000.

— 1987b, Geologic map of the Astoria and Ilwaco quadrangles, Washington and Oregon: Washington Division of Geology and Earth Resources Open File Report 87-2, scale 1:100,000.

Walsh, T. J., Korosec, M. A., Phillips, W. M., Logan, R. L., and Schasse, H. W., 1987, Geologic map of Washington-Southwest quadrant: Washington Division of Geology and Earth Resources Geologic Map GM-34, scale 1:250,000.

Walters, K. L., and Kimmel, G. E., 1968, Ground-water occurrence and stratigraphy of unconsolidated deposits, central Pierce County, Washington: Washington Department of Water Resources WaterSupply Bulletin 22, 428 p.

Weissenborn, A. E., 1969, Geologic Map of Washington: USGS Miscellaneous Geologic Investigations Map I-583, scale $1: 2,000,000$.

Wells, R. E., 1990, Paleomagnetic rotations and the Cenozoic tectonics of the Cascade arc, Washington, Oregon, and California: Journal of Geophysical Research B, v. 95, n. 12, p. 19,409-19,417.

Wells, R. E., Weaver, C. S., and Blakely, R. J., 1998, Fore-arc migration in Cascadia and its neotectonic significance: Geology, v. 26, p. 759-762.

Whetten, J. T., Carroll, P. I., Gower, H. D., Brown, E. H., and Pessl, F., Jr., 1988, Bedrock geologic map of the Port Townsend 30- by 60- minute quadrangle, Puget Sound region, Washington: U.S. Geological Survey Miscellaneous Investigations Series Map I-1198-G, scale 1:100,000.

Willis, B., 1903, Physiography and deformation of the Wenatchee-Chelan district, Cascade Range, in Contributions to the geology of Washington: U.S. Geological Survey Professional Paper 19, p. 41-97.

Yount, J. C., and Gower, H. D., 1991, Bedrock geologic map of the Seattle 30' by 60' quadrangle, Washington: U.S. Geological Survey Open-File Report 91-147, scale 1:100,000. 